No 2011 - 17

July

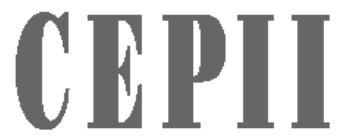

CENT T

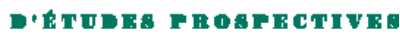

ET D'INOEMATIONS

INTEENATIONALE:

The "Forward Premium Puzzle" and the Sovereign Default Risk

Virginie Coudert

Valérie Mignon 


\section{TABLE OF CONTENTS}

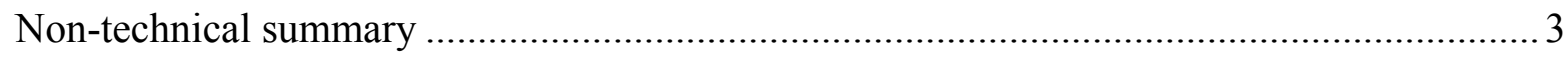

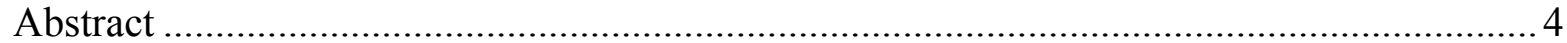

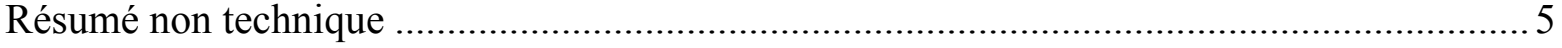

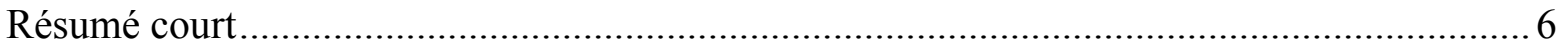

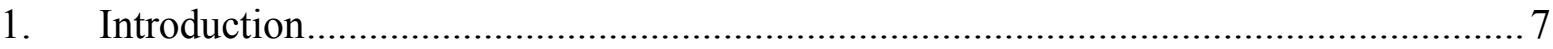

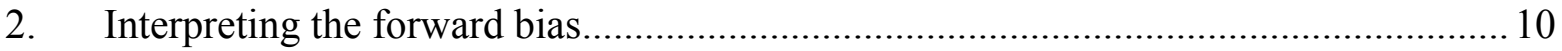

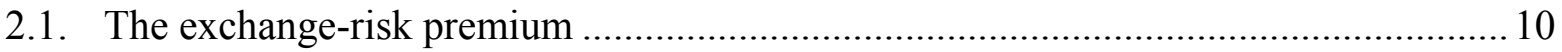

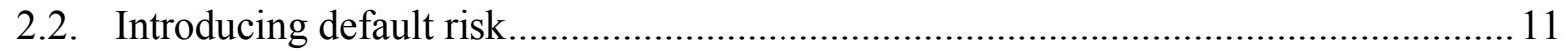

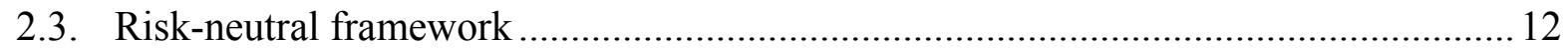

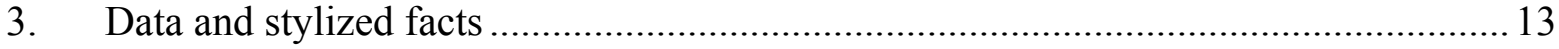

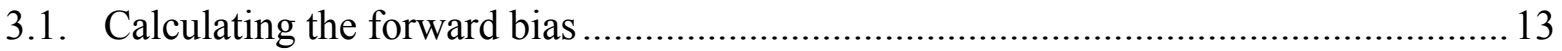

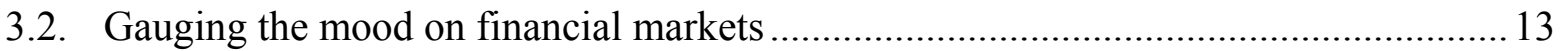

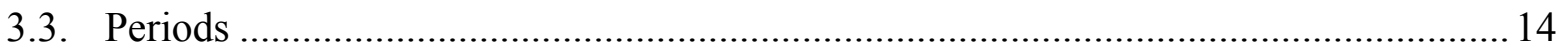

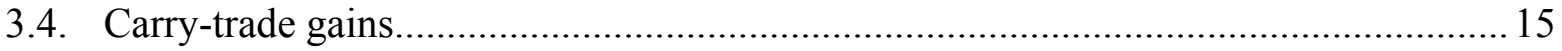

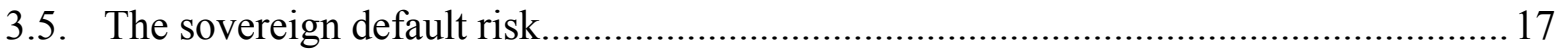

4. Estimating the relationship between carry-trade gains and default risk ...................... 18

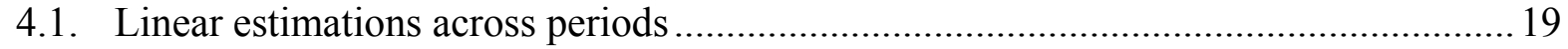

4.2. Nonlinearities depending on the jitteriness of financial markets ................................20

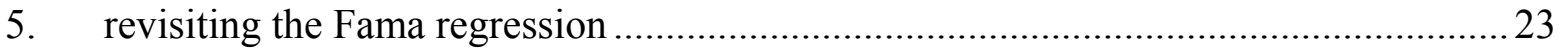

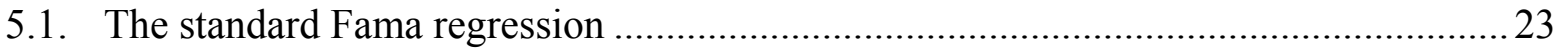

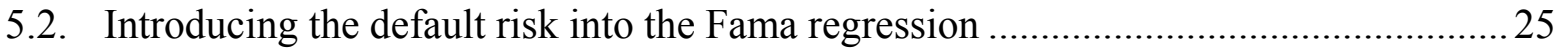

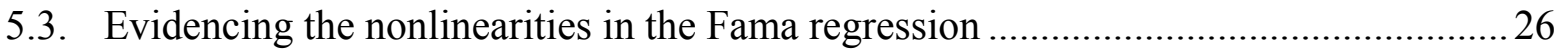

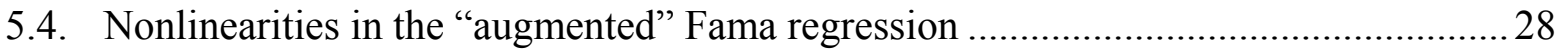

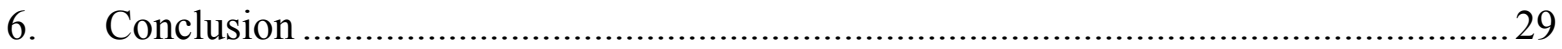

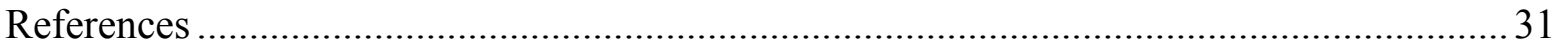

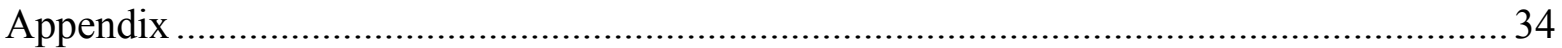

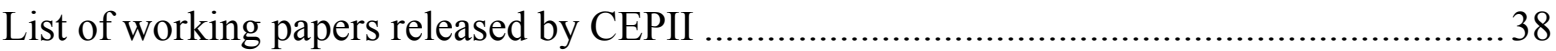


The “Forward PREMiUm PUZzLE” AND THE SOVEREIGN DEFAUlt Risk

\section{NON-TECHNICAL SUMMARY}

Buying forward high-yield currencies versus those with low interest rates has long been a very profitable strategy, because of the existence of a "forward bias". This has led to huge amounts of carry trades on the foreign exchange market. The excess returns in carry trades are still a puzzle for economists, often referred to as the "forward premium puzzle", which has given rise to an extensive literature. Here, we argue that this puzzle could be partially explained by taking into account the default risk, at least for emerging currencies. Indeed, a default of the banking system would lead to the impossibility for investors to recover their funds, which justifies their requiring a risk premium.

In this framework, we state the hypothesis that the default risk contributes to generate excess returns when financial markets are upbeat. During those periods, huge amounts of carry trades are accumulated in search for yield, as the riskiness of those positions is disregarded in a context of low risk aversion. We test this hypothesis empirically on a sample of daily data from June 2005 to September 2010.

As a sovereign default is likely to spark a default in the country's whole banking system, we proxy the default risk by the sovereign credit default swap (CDS) premia. We focus on a sample of 18 emerging countries, as they are the most likely to present a significant default risk. We calculate the gains of the carry trades funded in USD and invested in each of these currencies.

As the "forward bias" is only seen when risk aversion is low and tends to reverse during crisis, we split our sample into three sub-periods: a period of buoyant global markets, spanning from the beginning up to Lehman Brothers' failure in September 2008, a crisis up to October 2009, and a recovery period afterwards. We also run nonlinear, regime-switching models, the regression coefficients being dependent on the volatility in financial markets.

First, we show that the default risk increases the gains of carry trades in the buoyant period, and worsens the losses incurred during the crisis. More specifically, excess returns on emerging currencies are stronger when investing in countries with high default risk, during upbeat markets. However, when the level of nervousness on global financial markets overcomes a certain threshold, the losses are deeper for investments in those currencies.

Second we estimate the "Fama regression" that links the exchange-rate depreciation to the interest-rate differential in the previous period. If there were no forward bias, the interest differential would compensate for the depreciation in the currency, and the coefficient between these two variables should be equal to unity. Here we show that the higher the volatility on financial markets, the higher is the coefficient in the Fama regression. Finally, we introduce the default risk in the Fama regression and show that it is able to mitigate the forward bias. 


\begin{abstract}
Carry-trade strategies which consist of buying forward high-yield currencies tend to generate positive excess returns during long periods of time. Here, we aim at explaining this puzzle by the default risk, which is frequently taken on by investing in high-yield currencies. We empirically test for this hypothesis on a sample of 18 emerging currencies over the period from June 2005 to September 2010, the default risk being proxied by the sovereign credit default swap spread. Relying on smooth transition regression models, we show that default risk fuels the carry-trade gains during periods of upbeat financial markets, and worsens the losses in bear markets. We then introduce the default risk into the "Fama regression" linking the exchange-rate depreciation to the interest-rate differential. The "forward bias", usually evidenced by a coefficient smaller than unity in this regression, is somewhat alleviated, as the default risk partially explains the excess return.
\end{abstract}

JEL Classification: G15, G01, C3.

Keywords: $\quad$ Carry trades; Forward premium; UIP puzzle; Default risk; Smooth transition regression models. 
LE PARADOXE DE LA PRIME DE TERME ET LE RISQUE DE DÉFAUT SOUVERAIN

\section{RÉSUMÉ NON TECHNIQUE}

Acheter à terme des monnaies à haut rendement contre d'autres à bas taux d'intérêt est une stratégie qui s'est révélée profitable depuis longtemps, en raison de biais sur le taux de change à terme. Cette situation a suscité des montants importants de "carry trades " sur le marché des changes. Les excès de rendement générés par ces carry trades sont un paradoxe pour les économistes, souvent appelé le "paradoxe de la prime de terme », qui a donné lieu à une abondante littérature. Nous montrons ici que, pour les monnaies d'un panel de pays émergents, le paradoxe peut être partiellement résolu en prenant en compte le risque de défaut. Un défaut peut en effet conduire à l'impossibilité pour les investisseurs de recouvrer leurs fonds, ce qui justifie l'existence d'une prime de risque.

Dans ce contexte, nous posons l'hypothèse selon laquelle le risque de défaut d'un pays contribue à générer des excès de rendements sur sa monnaie pendant les périodes tranquilles. Durant ces périodes, d'importants montants de carry trades sont accumulés en vue de rendements futurs, le risque de telles positions étant ignoré en cas de faible aversion pour le risque. Nous testons cette hypothèse empiriquement sur un échantillon de données quotidiennes de juin 2005 à septembre 2010.

Le défaut souverain étant susceptible d'engendrer un défaut du système bancaire dans son ensemble, nous approximons le risque de défaut sur la devise par la prime de credit default swap (CDS) souverain. Nous nous concentrons sur un échantillon de 18 pays émergents car ils sont les plus susceptibles de présenter un risque de défaut significatif et étudions les gains de carry trades financés en dollar et investis dans les monnaies de notre panel.

Comme le biais du taux de change à terme est plus prégnant en cas de faible aversion pour le risque et tend à se renverser pendant les crises, nous séparons l'échantillon en trois souspériodes: une période tranquille s'étendant jusqu'à la faillite de Lehman Brothers en septembre 2008, une période de crise allant jusqu'à octobre 2009 et une période finale de reprise. Nous procédons en outre à l'estimation de modèles non linéaires à changement de régime, les coefficients des variables évoluant selon la volatilité sur les marchés financiers.

Premièrement, nous montrons que le risque de défaut accroît les gains de carry trades en période tranquille et aggrave les pertes lors des crises. Plus spécifiquement, les excès de rendements sur les devises sont favorisés par un risque de défaut souverain élevé lors de marchés faiblement volatils, alors que lorsque la volatilité dépasse un certain seuil, les pertes s'accroissent.

Deuxièmement, nous estimons la "régression de Fama », qui relie la dépréciation du taux de change au différentiel de taux d'intérêt de la période précédente. En l'absence de paradoxe, le différentiel d'intérêt devrait compenser la dépréciation du taux de change et le coefficient entre les deux variables est alors positif et égal à l'unité. Nous mettons ici en évidence que ce 
coefficient varie avec le degré de stress sur les marchés financiers. Enfin, nous introduisons le risque de défaut dans la régression de Fama et montrons que celui-ci explique en partie l'excès de rendement.

\section{RÉSUME COURT}

Les stratégies de carry trades qui consistent à acheter à terme des devises à haut rendement tendent à générer des excès de rendements durant de longues périodes. Nous cherchons ici à expliquer empiriquement ce paradoxe par le risque de défaut qui résulte d'un investissement en devises à haut rendement. A cette fin, nous considérons un échantillon de 18 pays émergents sur la période allant de juin 2005 à septembre 2010. En approximant le risque de défaut par la prime de credit default swap souverain, nous montrons, via l'estimation de modèles à changement de régime, que celui-ci stimule les gains de carry trades durant les périodes de faible volatilité sur les marchés financiers, alors qu'il aggrave les pertes en cas de crise. Nous introduisons en outre le risque de défaut dans la régression de Fama, reliant la dépréciation de la monnaie au différentiel de taux d'intérêt. Le paradoxe de la prime de terme, mis en évidence par un coefficient inférieur à l'unité dans cette régression, s'en trouve réduit, le risque de défaut expliquant une partie de l'excès de rendement.

Classification JEL : G15, G01, C3.

Mots-clés : $\quad$ carry trades ; paradoxe de la prime de terme ; risque de défaut ; modèles à transition douce. 


\title{
THE “ForWARd PREMIUM PUZZLE” AND THE SOVEREIGN DEFAUlt RisK
}

\author{
Virginie Coudert ${ }^{*}$ \\ Valérie Mignon $^{* *}$
}

\section{INTRODUCTION}

The existence of excess returns or forward biases on the exchange rate markets is one of the most famous puzzles in international economics, referred to as the "UIP puzzle"- since it is a breach in the uncovered interest parity (UIP) — or as the "forward premium puzzle" - since it contradicts the forward rate being the market rational expectation. In other words, interest differentials do not compensate for currency changes observed in the next period. This puzzle has been widely documented in the economic literature (for a survey, see Engel, 1995) and still gives rise to extensive research (Chaboud and Wright, 2005; Chinn, 2006; Clarida et al., 2009). This is a logical consequence of the findings by Meese and Rogoff (1983) that exchange rates follow a random walk. If exchange rates are expected to stay at their current values, then it is rewarding to invest in high-yield currencies by borrowing low-yield currencies, as one can expect to earn the interest-rate differential without losing on the exchange rate. For the same reason, it is profitable to buy forward a currency with a forward discount. Empirical evidence shows that currencies with high interest rates generally do not depreciate as much as the UIP would imply. On the contrary, they often appreciate slowly. Conversely, currencies with low interest rates do not appreciate as much as they should do if the UIP held; instead, they even tend to depreciate. Numerous studies have provided empirical evidence for these biases on various samples of currencies and periods (Lustig and Verdelhan, 2007; Burnside et al., 2008). Only Chinn (2006) has shown that the UIP could be restored at least for some currencies but only when considering long-run horizon of 5 years.

Hence, carry trades - which consist in taking long unhedged positions on currencies with high interest rates and short positions on low-interest rate currencies-have become an important activity on the exchange markets (Galati et al., 2007). They are especially popular when global financial markets are upbeat. The riskiness of these positions is disregarded during these periods as risk aversion is low and the search for yield wins over prudence. In these times, the built-up of carry-trade positions tends to strengthen the high-yield currencies. That is why carry trades are particularly profitable when volatility is low on global financial markets (Brunnermeir et al., 2008; Clarida et al., 2009). In contrast, during financial crises, carry-trade strategies abruptly unwind (Kohler, 2010; Coudert et al., 2011). Investors

\footnotetext{
Bank of France, CEPII, and EconomiX-CNRS, University of Paris Ouest, France. Email: virginie.coudert@banque-france.fr.

EconomiX-CNRS, University of Paris Ouest, and CEPII, France. Email: valerie.mignon@u-paris10.fr. We would like to thank Agnès Bénassy-Quéré, Gunther Capelle-Blancard and Mathieu Gex for very helpful comments.
} 
suddenly realize the riskiness of their strategies and sell the high-yield currencies, which sharply depreciate, whereas the low-interest currencies seen as safe-havens appreciate (Ranaldo and Söderlind, 2007; McCauley and McGuire, 2009). In the long run, despite the severe losses occurred during the reversals, carry trades are found profitable.

The existence of these excess returns has been explained by different theories, going from market frictions, namely transaction costs (Huisman et al., 1998) to a "career risk hypothesis" (Liu and Sercu, 2009) in which the traders on the forex market are incited to shun any cash loss from going against the flow. Indeed, as soon as investors are risk-averse, the expected returns in different currencies have no reasons to equalize. The UIP does not hold, as investors require a risk premium to hold the most risky currencies. This idea was already present in the portfolio models of the seventies (Frankel, 1973), in which the risk premia depended on the investors' positions. It is now apprehended through stochastic discount factors (SDF) in the framework of asset pricing based models (Cochrane, 2001), which are used to address the "equity premium puzzle" as well (Mehra and Prescott, 1985, 2003). For example, Verdelhan (2010) explains the exchange rate excess returns through a habit-based preferences model linking the exchange rate returns to the domestic consumption growth shocks under assumptions regarding the pro-cyclicity of real interest rates and time-varying risk aversion.

Another possible explanation for the puzzle goes through the "peso problem": the exchange rate risk premia would compensate agents for extremely negative returns, that they are exposed to with very low probabilities. Indeed, carry trades can be hedged against a sharp depreciation of their investment currency by buying a put option (or against the appreciation of the funding currency by a long position in a call). Holding a portfolio containing a carry trade and an option allows investors to hedge against negative events, while profiting from excess returns in the other states of nature. Using at-the-money option prices, Burnside et al. (2008) show that this portfolio also yields excess returns, not very different from those of the unhedged carry trades. This result is quite challenging, and the authors interpret it as a sign of a peso problem, coming from high SDF in the extremely unfavorable states of nature.

Here, we suggest a different interpretation of the forward premium puzzle based on the default risk. Indeed, an asset in a high-yield currency generally includes two types of risk: an exchange-rate risk and a default risk. Whereas the exchange-rate risk has been extensively studied, the default risk is generally neglected in the literature on carry trades. However, the recent global crisis has shown that this risk is not negligible as banks may collapse. A sovereign default can also spark a default of the whole banking system of the country and lead to the impossibility for investors to recover the totality of their funds.

In this framework, we show that the exchange-rate premium increases with the default risk. Then we state the hypothesis that the default risk of a country's banks tends to increase excess returns on its currency when financial markets are upbeat. In other words, default risk fuels the carry-trade gains in buoyant markets. Conversely, we expect that it also worsens the losses in bear markets. We test for this hypothesis empirically on a sample of daily data for 18 currencies from June 2005 to September 2010. We focus on emerging countries, as they are 
the most likely to present a significant default risk. We consider the gains of the carry trades invested in the 18 currencies and funded in USD. As the "forward bias" is especially high in upbeat markets and tends to reverse during crises, we split our sample into three sub-periods: a period of buoyant global markets up to Lehman Brothers' failure in September 2008, a crisis up to October 2009, and a recovery period afterwards.

First, we show that the default risk increases the gains of carry trades in the buoyant period, ${ }^{1}$ and worsens the losses incurred during the crisis. To this end, we run a regression explaining carry-trade gains by the default risk over the three sub-periods. The default risk on a currency is proxied by the sovereign credit default swap (CDS) premium of the country. As the impact of the default risk on the carry-trade gains highly depends on the period, we account for nonlinearities by estimating a smooth-transition regression (STR) model. We use the VIXwhich measures the implied volatility on the S\&P500 index-as the transition variable between low and high-volatility regimes. We show that default risk increases the carry-trade gains during low-volatility periods. On the contrary, when volatility exceeds a certain threshold, the higher the volatility, the more the default risk reduces the carry-trade gains.

Second, we verify that the above results do not come from a correlation between interest rate and default risk. To tackle this issue, we begin by estimating the "Fama regression" (Fama, 1984) that links the exchange-rate depreciation to the interest-rate differential in the previous period. If there was no forward bias, the coefficient between the two variables would be equal to unity. Our results are in line with those of Brunnermeir et al. (2008) and Clarida et al. (2009) since we show that the coefficient of the regression is often negative when volatility is low in financial markets, and switch to very positive values in high-volatility periods. To account for this nonlinear, regime-dependent behavior, we contribute to the literature by estimating the Fama regression using a STR specification. We show that the coefficient of the Fama regression increases when the VIX overcomes a certain threshold. Then we introduce a default risk term into the Fama regression, and show that it is a significant variable. Moreover, the bias in the coefficient of the Fama regression is mitigated by introducing this term. Here again, this lends support for our hypothesis that the default risk contributes to the forward bias.

The rest of the paper is organized as follows. Section 2 shows that the exchange-rate premium increases with the default risk. Section 3 presents the data and stylized facts about the gains of carry-trades invested in emerging currencies. Section 4 gives econometric estimations of the relationship between the carry-trade gains and the default risk. Section 5 provides nonlinear estimations of the Fama regression according to the volatility in financial markets and proposes an "augmented Fama regression" by introducing the default risk into the model. Section 6 concludes.

\footnotetext{
${ }^{1}$ In other words, when financial markets are booming, a rise in the default risk increases the return of the corresponding currency.
} 


\section{INTERPRETING THE FORWARD BIAS}

\subsection{The exchange-risk premium}

Let us take the point of view of a risk-averse US resident investing in a foreign currency from $t$ to $t+1$ while funding in USD. There are no restrictions in capital movements between the two countries, no risk of default in both countries. Her foreign currency investment gives the following ex post excess return in USD, denoted $r_{t+1}$ and expressed as follows:

$$
\left(1+r_{t+1}\right)=\frac{\left(1+i_{t}\right)}{\left(1+i_{t}^{U S}\right)} \frac{S_{t}}{S_{t+1}}
$$

where $i_{t}$ is the interest rate in the foreign country, $i_{t}^{U S}$ the US interest rate and $S_{t}$ is the exchange rate of the foreign currency against the USD, measured as the number of units of the foreign currency for one dollar.

This excess return is the yield of the carry trade invested in the foreign currency, while funded in USD. The exchange-rate risk premium $\rho_{t}^{S}$ is defined as this expected excess return on the foreign currency:

$$
\left(1+\rho_{t}^{S}\right)=E_{t}\left[\frac{1+i_{t}}{1+i_{t}^{U S}} \frac{S_{t}}{S_{t+1}}\right]=E_{t}\left(1+r_{t+1}\right)
$$

where $E_{t}\left[X_{t+1}\right]$ stands for the agents' expectation on $X_{t+1}$ at time $t$.

The exchange-rate premium is equivalent to the expected return of buying the foreign currency forward and selling it in the next period on the spot market. Hence, it is also referred to as the "forward premium", or the "forward bias". In other words, the exchange-rate premium is equivalent to the gap between the forward rate $F_{t}$ and the expected spot rate for the next period.

$$
\left(1+\rho_{t}^{S}\right)=E_{t}\left[\frac{1}{S_{t+1}}\right] F_{t}
$$

As all risk premiums, in the framework of an asset pricing model (see Cochrane, 2001), the exchange-rate premium can be written as:

$\rho_{t}^{S}=-\operatorname{cov}\left(r_{t+1}^{s}, m_{t+1}\right) \frac{1}{E_{t}\left[m_{t+1}\right]}$

where $m_{t}$ is the stochastic discount factor (SDF), which depends on the inter-temporal utility function of a representative agent. A positive risk premium, $\rho_{t}>0$, is the standard situation 
for a risky asset for which the covariance of its return with the SDF is negative. Indeed, large positive returns occur in the favourable states of nature with low SDF, typically when market returns are high; conversely, low returns are observed in the unfavourable states of nature, which have high SDF, typically during financial crises, when all asset prices plummet. As the exchange rate is a relative price between two countries' assets, the risk premium is symmetrical: Equation (2) being symmetrical, the excess return for a US investor is the opposite of the excess return for a foreign investor. This means that if some currencies have positive risk premiums, others necessarily have negative ones.

Equation (3) states that currencies bear positive exchange risk premiums, if their returns are positively correlated to markets returns (i.e. negatively correlated to the SDF). In other words, currencies which yield positive returns during bull markets and depreciate in bear markets should offer positive risk premiums to compensate for their risks. These positive correlations with market returns characterize most emerging countries' currencies, as this will be illustrated in Section 3. Hence, they bear positive exchange-rate premiums and exhibit positive "forward biases".

Conversely, currencies which are able to offer returns negatively correlated to market returns have negative risk premia. These latter currencies can be viewed as safe havens, as they tend to appreciate in the unfavourable states of nature (such as the Japanese yen or the Swiss franc for example).

\subsection{Introducing default risk}

We now consider a one-period investment in the foreign country when a default is possible. The default will occur during this period with a given probability $p, 0<p<1$. In this case, the ex post return of this investment is:

$$
\left\{\begin{array}{c}
1+r_{t+1}=\frac{1+i_{t}}{1+i_{t}^{U S}} \frac{S_{t}}{S_{t+1}} \quad \text { if no default } \\
1+r_{t+1}=\mu \frac{1+i_{t}}{1+i_{t}^{U S}} \frac{S_{t}}{S_{t+1}} \text { if default }
\end{array}\right.
$$

where $\mu$ is the recovery rate, $0<\mu<1$.

The risk premium on this investment, denoted $\rho_{t}^{T}$, now stems from two factors: the exchange-rate risk premium $\rho_{t}^{S}$, as in the previous section, and the default risk premium. It can be expressed as:

$$
\left(1+\rho_{t}^{T}\right)=E_{t}\left[\frac{1+i_{t}}{1+i_{t}^{U S}} \frac{S_{t}}{S_{t+1}}\left[1-I_{t+1}(1-\mu)\right]\right]
$$


where $I_{t}$ is the indicator function of default (equal to 1 in case of default, 0 otherwise). Replacing the exchange-rate premium $\left(1+\rho_{t}^{S}\right)$ by its value as in Equation (2), we can re-write Equation (5) as the following:

$$
\left(1+\rho_{t}^{T}\right)=\left(1+\rho_{t}^{S}\right)[1-p(1-\mu)]+(1-\mu) \operatorname{Cov}_{t}\left[\left(s_{t+1}-s_{t}\right), I_{t+1}\right]
$$

Let us remark that the quantity $p(1-\mu)$ stands for the expected loss on the investment due to default, at constant exchange rates, which can be thought of as the default risk premium, which we denote $d$ :

$d=p(1-\mu)$

The covariance $\quad$ term can be cospred
$\operatorname{Cov}_{t}\left[\left(s_{t+1}-s_{t}\right), I_{t+1}\right]=p\left[E_{t}\left[\left(s_{t+1}-s_{t}\right) / I_{t+1}=1\right]-E_{t}\left[s_{t+1}-s_{t}\right]\right]$

where $E_{t}\left[\left(s_{t+1}-s_{t}\right) / I_{t+1}=1\right]$ stands for the expected depreciation given default.

The exchange-rate premium can therefore be written as:

$$
\left(1+\rho_{t}^{S}\right)=\frac{\left(1+\rho_{t}^{T}\right)-d\left[E_{t}\left[\left(s_{t+1}-s_{t}\right) / I_{t+1}=1\right]-E_{t}\left(s_{t+1}-s_{t}\right)\right]}{1-d}
$$

Equation (8) shows that the exchange risk premium is likely to a positive function of the default risk premium $d$ under reasonable assumptions on the parameters. (i) If the investment in the foreign currency is considered as risky, theoretically, the total risk premium $\rho_{t}^{T}$ should be positive. (ii) The covariance term is also positive as a default generally sparks a depreciation in the currency, however it is likely to be much smaller than 1 . Hence, $\rho_{t}^{S}$ is a positive function of $d$. In other words, the exchange-risk premium positively depends on the default premium.

\subsection{Risk-neutral framework}

To better clarify the link between the exchange-rate premium and the default risk, let us consider a risk-neutral approach. In this framework, the total risk premium $\rho_{t}^{T}$ on the foreign investment is null. As investors disregard the risk, there are no expected excess returns. Therefore, Equation (5) would be expressed as:

\footnotetext{
2 It even stays smaller than 1 under unrealistically pessimistic assumptions. For instance if $p=30 \%$, the depreciation in case of default at $80 \%$ (above the unconditional depreciation) and $\mu=30 \%$, the covariance term $(0.84)$ is still smaller than 1 .
} 
$1=E_{t}^{R N}\left[\frac{1+i_{t}}{1+i_{t}^{U S}} \frac{S_{t}}{S_{t+1}}\left[1-I_{t+1}(1-\mu)\right]\right]$

where $E_{t}^{R N}\left[X_{t+1}\right]$ is the expected value of $X_{t+1}$ under the risk-neutral distribution.

In the risk-neutral approach, the foreign exchange premium still exists. It compensates riskneutral investors for the expected loss due to a possible default:

$\left(1+\rho_{t}^{R N, S}\right)=\frac{1}{1-d}\left[1-d\left[E_{t}^{R N}\left[\left(s_{t+1}-s_{t}\right) / I_{t+1}=1\right]-E_{t}^{R N}\left[\left(s_{t+1}-s_{t}\right)\right]\right]\right]$

where $\rho_{t}^{R N, S}$ stands for the risk-neutral exchange-rate premium. In this framework, the exchange-rate premium only stems from the possibility of default.

\section{DATA AND STYLIZED FACTS}

\subsection{Calculating the forward bias}

We consider the gains in investing in emerging currencies, while funding in USD. The sample is made of the currencies of the main emerging countries for which there is capital mobility, hence the possibility of carry trades. It includes 18 currencies in Latin America, those of Argentina (ARS), Brazil (BRL), Chile (CLP), Colombia (COP), Mexico (MXN), Peru (PEN); in Asia, Indonesia (IDR), Korea (KRW), Malaysia (MYR), Philippines (PHP), Thailand (THB); in emerging Europe, the Czech Republic (CZK), Hungary (HUF), Poland (PLN), Romania (RON), as well as the Russian rouble (RUB), the Israel shekel (ILS) and the South African rand (ZAR).

For all these currencies, we consider the one-year change in their exchange rate versus dollar (in logarithms), and the one-year interest rate taken in difference with the one-year interest rate in the US, all series being extracted from Bloomberg. The choice of a one-year horizon is justified in Section 3.5 below.

\subsection{Gauging the mood on financial markets}

To gauge the mood on the global financial markets, we use the VIX. This indicator measures the implied volatility of the S\&P500 index options for the next 30 days, calculated by the Chicago Board Options Exchange (CBOE). We extract it from Bloomberg.

This variable is a good proxy for assessing the financial market mood (see Becker et al., 2009). First, a low volatility on the stock market generally matches an upbeat mood with low risk-aversion, whereas high volatility typically goes with bear markets. Second, strong spillovers in stock market volatility all around the world make the situation on the S\&P500

\footnotetext{
${ }^{3}$ We retain only main emerging countries, as we need daily data for sovereign CDS premia, which requires an active market.
} 
representative of the global financial markets. Hence the VIX can be considered as a reliable indicator of risk aversion on global financial markets (Coudert and Gex, 2009).

\subsection{Periods}

The sample period spans from June 2005 to September 2010 on a daily periodicity. To investigate the effect of financial stress on the carry-trade strategies, we split it into three subperiods:

- Period 1: upbeat financial markets in a context of low volatility. The period is characterized by weak risk-aversion, as attested by narrow credit spreads and bull stock markets. We date this period from the beginning of the sample (1st June 2005) up to the Friday 12 September 2008, the working day before the failure of Lehman Brothers;

- Period 2: the global financial crisis, from 15 September 2008 to 30 September 2009;

- Period 3: recovery. We date the recovery from 1rst October 2009, as attested by capital flowing back to emerging countries. At that time, Brazil implemented a new tax on capital inflows to counter the appreciation in its exchange rate; most other emerging currencies also appreciated strongly.

The evolution of the VIX fits the dates of these periods (Figure 1). On Monday 15 September 2008, Lehman Brothers' bankruptcy violently hit the financial markets, sparking a sharp jump in the VIX, from a level of about $25 \%$ up to $80 \%$ in a few days. The end of the crisis is dated at the end of September 2009, when the VIX went back to its pre-crisis level.

Figure 1. VIX index (in \%) and the three sub-periods

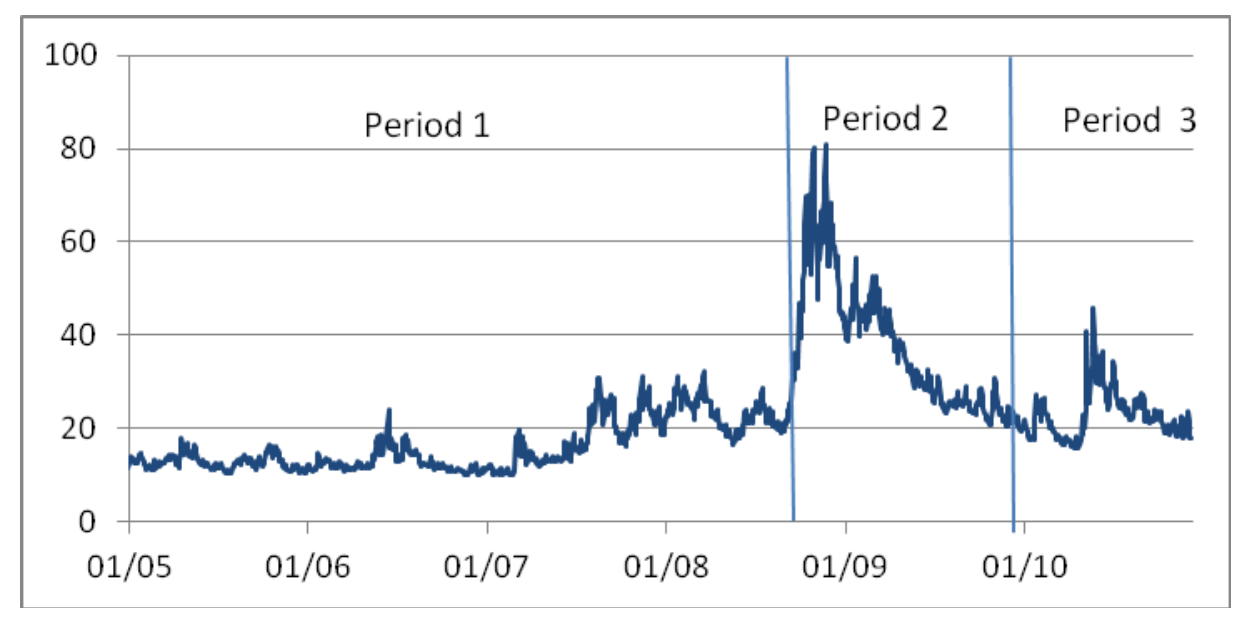

Source: Bloomberg. 


\subsection{Carry-trade gains}

We now take a look at the returns of the carry trades invested in the different currencies of the sample and funded in USD. Using Equation (4), as no default occurred in the sample period, carry-trade gains are expressed as: $\left(1+r_{t+1}\right)=\frac{\left(1+i_{t}\right)}{\left(1+i_{t}^{U S}\right)} \frac{S_{t}}{S_{t+1}}$

Table 1 displays these one-year carry-trade excess returns for each of the currencies in the sample, along with their average interest-rate differentials with the US and their one-year depreciation against USD. The excess returns are positive on average during the upbeat period, for all currencies, except one (South Africa). Confirming the "forward bias puzzle", the positive excess returns stem from both positive interest-rate differentials and currency appreciation for most countries. On the top of being more profitable, carry-trade gains also exhibit lower volatility in this period of buoyant market.

Table 1. Average interest-rate differentials with the US, one-year change in the exchange rates vs. USD, and one-year carry-trade excess returns, in \%

\begin{tabular}{|c|c|c|c|c|c|c|c|c|c|c|c|c|}
\hline & \multicolumn{3}{|c|}{ Period 1: } & \multicolumn{4}{|c|}{ Period 2: } & \multicolumn{4}{|c|}{ Period 3: } & \\
\hline & \multicolumn{3}{|c|}{ tranquil period } & \multicolumn{4}{|c|}{ cris is } & \multicolumn{4}{|c|}{ recovery } & \\
\hline & \multicolumn{3}{|c|}{$01 / 06 / 2005-12 / 09 / 2008$} & \multicolumn{4}{|c|}{$15 / 09 / 2008-30 / 09 / 2009$} & \multicolumn{4}{|c|}{$1 / 10 / 2009-30 / 09 / 2010$} & \\
\hline & $\begin{array}{l}\text { Interest } \\
\text { rate } \\
\text { differential }\end{array}$ & $\begin{array}{c}\text { Exchang } \\
\text { e rate } \\
\text { ch an ge }\end{array}$ & $\begin{array}{l}\text { Excess } \\
\text { returns }\end{array}$ & Vo latility & $\begin{array}{l}\text { In terest rate } \\
\text { differen tial }\end{array}$ & $\begin{array}{c}\text { Exchange } \\
\text { rate } \\
\text { change }\end{array}$ & $\begin{array}{l}\text { Excess } \\
\text { returns }\end{array}$ & Vo lat il ity & $\begin{array}{l}\text { In terest } \\
\text { rate } \\
\text { differential }\end{array}$ & $\begin{array}{c}\text { Exch an ge } \\
\text { rate } \\
\text { change }\end{array}$ & $\begin{array}{l}\text { Excess } \\
\text { returns }\end{array}$ & Vo latility \\
\hline A rgentina & 5.5 & 1.7 & 3.9 & 3,0 & 11.4 & 13.8 & -2.5 & 7,5 & 19.2 & 7.1 & 12.1 & 6,6 \\
\hline Braz il & 11.6 & -14.7 & 26.2 & 7,3 & 8.2 & 20.7 & -12.5 & 9,9 & 9.2 & -18.2 & 27.4 & 16,7 \\
\hline Chile & -4.0 & -6.3 & 2.3 & 6,1 & -2.9 & 18.2 & -21.1 & 10,0 & -1.7 & -12.5 & 10.9 & 12,9 \\
\hline Colombia & 3.0 & -8.1 & 11.1 & 8,7 & 5.6 & 15.6 & -10.0 & 10,2 & 5.9 & -14.7 & 20.7 & 13,5 \\
\hline M exico & 3.7 & -1.9 & 5.6 & 3,8 & 4.4 & 22.9 & -18.5 & 7,2 & 4.4 & -5.4 & 9.8 & 11,4 \\
\hline Peru & 0.0 & -4.1 & 4.1 & 4,7 & 2.1 & 5.0 & -2.9 & 4,8 & 0.2 & -7.4 & 7.6 & 6,0 \\
\hline Korea & -0.1 & -3.0 & 2.9 & 5,0 & 2.4 & 28.6 & -26.2 & 4,5 & 2.2 & -12.6 & 14.8 & 6,1 \\
\hline Ind ones ia & 5.9 & -0.1 & 6.0 & 5,8 & 5.6 & 14.4 & -8.9 & 7,6 & 8.3 & -15.4 & 23.7 & 11,2 \\
\hline M al ay sia & -1.1 & -4.4 & 3.4 & 2,7 & 0.2 & 7.8 & -7.6 & 4,1 & 0.6 & -7.9 & 8.5 & 6,1 \\
\hline Philippines & 3.3 & -7.7 & 11.0 & 5,1 & 2.5 & 10.4 & -8.0 & 4,6 & 2.5 & -4.5 & 7.1 & 8,4 \\
\hline Thailand & -0.4 & -5.7 & 5.4 & 6,5 & 0.2 & 4.5 & -4.2 & 11,9 & 0.3 & -6.4 & 6.8 & 16,2 \\
\hline Czech Rep. & -1.8 & -10.8 & 9.1 & 3,4 & 0.6 & 13.1 & -12.5 & 11,2 & 1.1 & -2.7 & 3.8 & 13,2 \\
\hline H ungary & 3.4 & -4.8 & 8.2 & 7,5 & 4.7 & 20.3 & -15.6 & 7,1 & 7.5 & -1.5 & 9.0 & 14,2 \\
\hline Poland & 0.7 & -10.8 & 11.5 & 9,7 & 2.7 & 27.6 & -24.9 & 11,3 & 3.1 & -4.2 & 7.3 & 13,7 \\
\hline Roman ia & 4.8 & -7.5 & 12.3 & 11,0 & 6.5 & 23.3 & -16.8 & 10,3 & 10.8 & 2.0 & 8.8 & 15,0 \\
\hline Russia & 3.0 & -4.9 & 7.9 & 9,0 & 4.0 & 24.0 & -19.9 & 15,8 & 13.7 & -3.5 & 17.2 & 18,5 \\
\hline Is rael & 0.6 & -5.9 & 6.6 & 7,2 & 1.2 & 7.7 & -6.5 & 16,1 & 0.1 & -4.4 & 4.4 & 15,5 \\
\hline So uth A frica & 4.0 & 5.5 & -1.5 & 8,2 & 8.9 & 18.3 & -9.4 & 10,0 & 7.2 & -18.3 & 25.5 & 9,6 \\
\hline A verage & 2.2 & -5.8 & 8.1 & 6,4 & 3.5 & 16.3 & -12.9 & 9,1 & 5.1 & -6.6 & 11.8 & 11,9 \\
\hline
\end{tabular}

Source: authors' calculations. Excess returns = interest rate differential - exchange-rate change. "Average" is the unweighted average. 
Strikingly, all the excess returns suddenly fell to very negative values during the crisis. Interest-rate differentials stayed positive and even slightly increased on average, but currencies depreciated dramatically, losing $16.3 \%$ on average. Meanwhile, their volatility soared in most cases. The recovery period is characterized by a renewal of carry-trade gains: returns went back to the positive territory for all currencies, due to both positive interest-rate differentials and currency appreciation, although volatility remained high due to the persistent jitteriness of markets.

Figure 2 depicts the pattern in the carry-trade gains for four countries: Brazil, Mexico, Philippines and Russia. The four charts show how abrupt the reversal of carry-trade gains was during the crisis. Returns became negative only a few days after the Lehman Brothers' bankruptcy. They turned positive again in late 2009, as capital flowed back to emerging countries.

Figure 2. Returns on a one-year carry trade funded in USD and invested in local currency, in \%

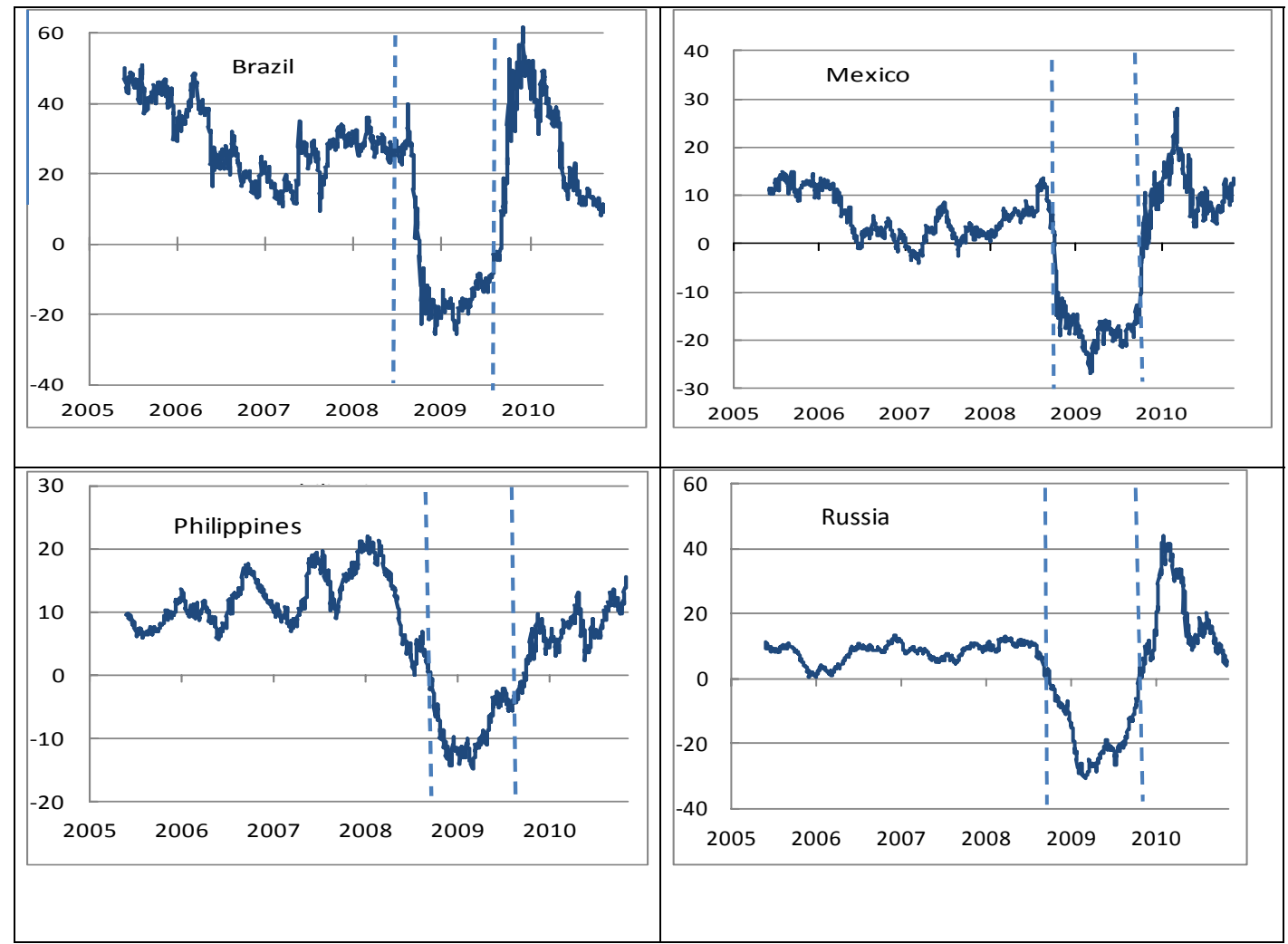

Note: Dotted vertical lines indicate the start and the end of the crisis period. Source: authors' calculations. 


\subsection{The sovereign default risk}

We proxy the default risk on the investment in a given currency by the sovereign CDS premium of the country. The sovereign default is able to represent the default of the country's banks, as both credit events are highly correlated because of the close financial interactions between the two types of agents.

The CDS premium is a good proxy for the default risk premium. It is roughly equal to the default risk premium $d=p(1-\mu)$ in Equation (6). As the CDS is aimed at hedging the default risk, holding a portfolio including a bond and a CDS is equivalent to a risk-free asset. Consequently, the return on this portfolio, which is equal to the bond yield $y$ less the CDS premium $d$, should also be equal to the risk-free rate $r$. This implies that $y$ - $d=r$. Hence, the CDS premium is equal to the bond spread $d=y-r$.

We extract the one-year sovereign CDS premia from Datastream. We choose a one-year horizon which is the smallest maturity for the CDS data. Of course, to compare this default risk to the exchange-rate risk, we also have to consider the same one-year maturity for interest rates and exchange-rate changes.

The sovereign CDS premia suddenly soared during the crisis. On average on our sample, they rose from 35 basis points in the upbeat period to 401 in the crisis, as shown in Table A.1 in the Appendix. This evolution is observed for each country of the sample. It is illustrated by Figure 3 for four selected countries. 
Figure 3. CDS premia, in basis points

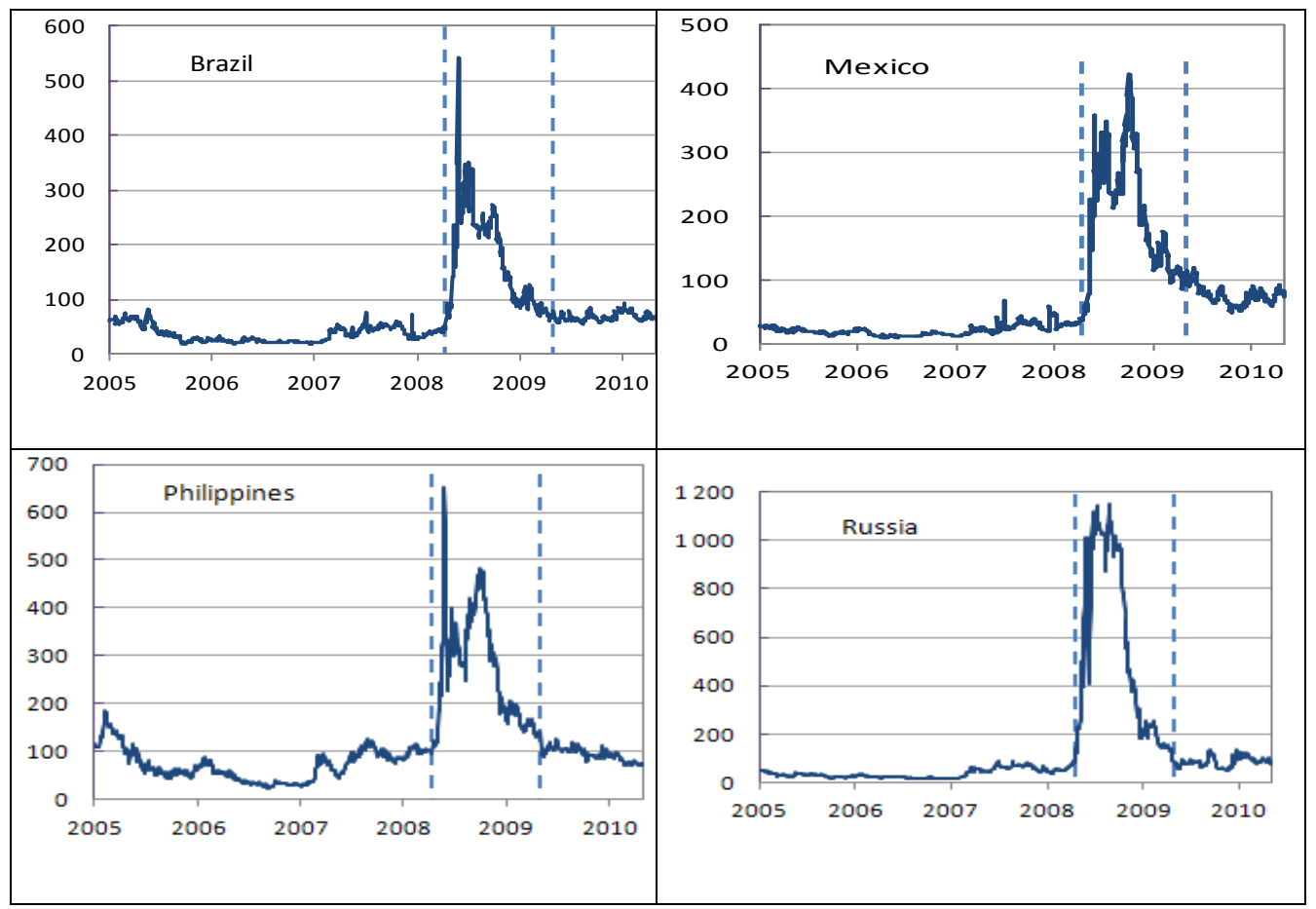

Note: Dotted vertical lines indicate the start and the end of the crisis period. Source: authors' calculations.

\section{ESTIMATING THE RELATIONSHIP BETWEEN CARRY-TRADE GAINS AND DEFAULT RISK}

The previous stylized facts suggest a positive correlation between the carry-trade gains invested in emerging currencies and global market returns. This implies a positive exchangerisk premium for these currencies, as stated by Equation (3). Hence, ex post carry-trade gains tend to be positive on average and to co-move with market returns. As the exchange-rate premium positively depends on the default risk (Equation (8)), the correlation of carry-trade gains with the market mood is likely to be increased by the default risk. To check for this hypothesis, we aim at empirically verifying the two following propositions:

(P1) "The carry-trade gains observed during periods of upbeat markets are higher when invested in countries with higher default risk”.

(P2) "Conversely, the losses on carry trades during crises are deeper for high default risk currencies".

These two propositions stem from the same hypothesis that the risk premium on carry trades invested in emerging currencies is positive and comes from both exchange rate and default risk, as seen in Equation (8). 


\subsection{Linear estimations across periods}

We first estimate the direct link between the ex post returns on carry trades and the default risk, proxied by the sovereign CDS premia. To do so, we run the following regressions successively for the 18 currencies of the sample:

$r_{i t+1}=\lambda_{i} d_{i t}+\alpha_{i}+\varepsilon_{i t+1}$

where $r_{i t+1}$ is the ex post excess return in the one-year carry trade invested at time $t$ in currency $i(i=1, \ldots, 18), d_{i t}$ is country $i$ 's default risk proxied by its sovereign CDS premium.

To establish proposition (P1), we have to find the coefficients $\lambda_{i}$ significantly positive when estimated over the upbeat market period. Conversely for proposition (P2) to hold, we should find the $\lambda_{i}$ significantly negative over the crisis.

The estimations are run on the three sub-periods under study: upbeat market period, crisis, and recovery (see Section 3.3). Carry-trade gains are measured over one year but are observed at a daily frequency. This leads to an overlapping structure that introduces a moving average component in the errors. To correct for this issue, we rely on the Newey and West (1987)'s autocorrelation and heteroskedasticity consistent covariance estimator. ${ }^{4}$

The results obtained by running regression (11) on each of the 18 currencies lend support to the two propositions. As expected, all coefficients $\lambda_{i}$ are significantly positive in the first period (except only for 2 currencies) and also for the recovery period (Table A.2 in the Appendix). Conversely, all coefficients $\lambda_{i}$ are significantly negative when estimated over the crisis. To further check the results, we also run regression (11) with panel data (Table 2). The first panel includes all the 18 currencies in the sample, whereas the others group together the countries belonging to the same geographic areas (Latin America, Asia, and emerging Europe). All estimated coefficients confirm the two propositions above, as they switch from positive to negative values from the first to the second period, and become again positive in the last, recovery period.

On the whole, the default risk contributes to amplify the carry-trade gains when markets are upbeat. On the other hand, it worsens the losses during the crisis. Here, it is important to remember that this situation prevails even if there was no default observed over the sample during the crisis. The carry-trade losses only occurred through exchange-rate depreciation.

\footnotetext{
${ }^{4}$ Note that the distribution of the t-ratios under overlapping observations are more fat-tailed-and thus depart from the standard normal distribution - than the OLS t-ratios. However, as highlighted by Mark (2001), this mainly concerns very small samples, justifying the use of the Newey and West estimator in our case.
} 
Table 2. Estimated coefficients $\lambda_{i}$ by sub-periods (panel estimation)

\begin{tabular}{lccc}
\hline Panel $i$ & Period 1 & Period 2 & Period 3 \\
\hline Whole sample & 6.338 & -0.518 & 2.774 \\
& $(25.799)$ & $(-27.542)$ & $(39.897)$ \\
\hline Latin America & 4.645 & -0.151 & 1.911 \\
& $(23.416)$ & $(-16.290)$ & $(56.085)$ \\
\hline Asia & 8.635 & -4.392 & 15.686 \\
& $(30.137)$ & $(-55.561)$ & $(48.603)$ \\
\hline Emerging Europe & 27.170 & -3.822 & 3.795 \\
& $(46.980)$ & $(-28.821)$ & $(8.479)$ \\
\hline
\end{tabular}

Note: This table reports the results from the estimation of Equation (11): $r_{i t+1}=\lambda_{i} d_{i t}+\alpha_{i}+\varepsilon_{i t+1}$ where $r_{i t+1}$ is the ex post excess return in the one-year carry trade invested at time $t$ in currency $i$ and $d_{i t}$ is country $i$ 's default risk proxied by its sovereign CDS premium. $t$ statistics are given in parentheses.

\subsection{Nonlinearities depending on the jitteriness of financial markets}

As the relation between carry-trade gains and default risk is reversed during crises, it is interesting to study how it evolves along with the jitteriness of financial markets. Indeed, carry-trade gains are highly dependent on the financial market mood, which determines the level of risk-aversion and also modulates the perceived quantity of risk.

To address this issue more precisely, we investigate how the link between both variables varies with the level of financial stress measured by the VIX. To do so, we use a smooth transition regression (STR) model. According to this specification, the carry-trade gains depend nonlinearly on the default risk, their relationship being dependent on the level of the VIX. More specifically, our STR model is given by:

$r_{i t+1}=\lambda_{0 i} d_{i t}+\alpha_{0 i}+\left[\lambda_{1 i} d_{i t}+\alpha_{1 i}\right] g\left(v_{t} ; \gamma_{i}, c_{i}\right)+\varepsilon_{i t+1}$

where $\varepsilon_{i t}$ is $\operatorname{iid}\left(0, \sigma_{i \varepsilon}^{2}\right), v_{t}$ is the VIX which acts as the transition variable and $g\left(v_{t} ; \gamma_{i}, c_{i}\right)$ is the transition function which by convention is bounded by zero and one. $\gamma_{i}>0$ denotes the slope parameter that determines the smoothness of the transition from one regime to the other (i.e. the abruptness of the transition dynamics at $c_{i}$ ), and $c_{i}$ is the threshold parameter.

In this model, two regimes - linear and nonlinear - characterize the dynamics of the carrytrade gains, depending on market volatility. The transition from one regime to the other is smooth, implying that there exists a continuum of states between extreme regimes. Two transition functions are commonly considered (Teräsvirta and Anderson, 1992):

$$
\begin{aligned}
& g\left(v_{t} ; \gamma_{i}, c_{i}\right)=\left(1+\exp \left(-\gamma_{i}\left(v_{t}-c_{i}\right)\right)\right)^{-1}: \text { logistic STR model (LSTR) } \\
& g\left(v_{t} ; \gamma_{i}, c_{i}\right)=1-\exp \left(-\gamma_{i}\left(v_{t}-c_{i}\right)^{2}\right): \text { exponential STR model (ESTR) }
\end{aligned}
$$


The LSTR specification accounts for asymmetric realizations, in the sense that the two regimes are associated with small and large values of the transition variable relative to the threshold value. On the other hand, in the ESTR model, increases and reductions in the transition variable have similar effects, but the middle grounds are characterized by different dynamics. In both cases - LSTR and ESTR — when $\gamma_{i}$ goes to zero, the STR process reduces to a linear model. When $\gamma_{i}$ tends to infinity, the LSTR model becomes a two-regime threshold model with abrupt transition (Tong, 1990). To specify the STR model, we follow the methodology proposed by Teräsvirta (1994). We first test for linearity and, if the null hypothesis is rejected, choose between the LSTR and ESTR specifications using the sequential strategy developed by Teräsvirta (1994). Once this choice has been made, we estimate the STR model and apply various misspecification tests: test of no residual autocorrelation (Teräsvirta, 1998), LM-test of no remaining nonlinearity (Eitrheim and Teräsvirta, 1996), and ARCH-LM test (Engle, 1982).

The nonlinear form of the relationship is confirmed as the null hypothesis of linearity is rejected, for all our 18 currencies. Hence, the response of the carry-trade gains to the CDS spread does differ according to the level of financial volatility. Moreover, the LSTR specification is retained for all the currencies. This means that there are two regimes involved. The first one prevails when the volatility is low on financial markets, the VIX being under the estimated threshold $c_{i}$. The relationship between carry-trade gains and default risk then only involves the linear parameter $\lambda_{0 i}$, as the second term in the right-hand side of Equation (12) is close to 0 ( $g$ being close to 0 ). The second, high-volatility regime occurs when the VIX exceeds the threshold, the relationship then also includes the second term of Equation (12) and coefficient $\lambda_{1 i}$ is involved (as well as the sum of $\lambda_{0 i}$ and $\lambda_{1 i}$ ).

Several features evidenced by the results reported in Table 3 confirm our former hypothesis. First, when volatility is low on financial markets, the relationship between carry-trade gains and default risk is significantly positive in most cases. This is evidenced by $\lambda_{0 i}>0$ for 13 currencies out of 18. Second, when financial markets get jitter, the relationship turns negative (for 14 cases in 18). Third, the level of the VIX that determines the two regimes varies across countries.

\footnotetext{
5 To save space, results of both linearity and misspecification tests are not reported here but are available upon request to the authors.
} 
Table 3. Coefficient $\lambda_{i}$ in the nonlinear estimations (country-by-country)

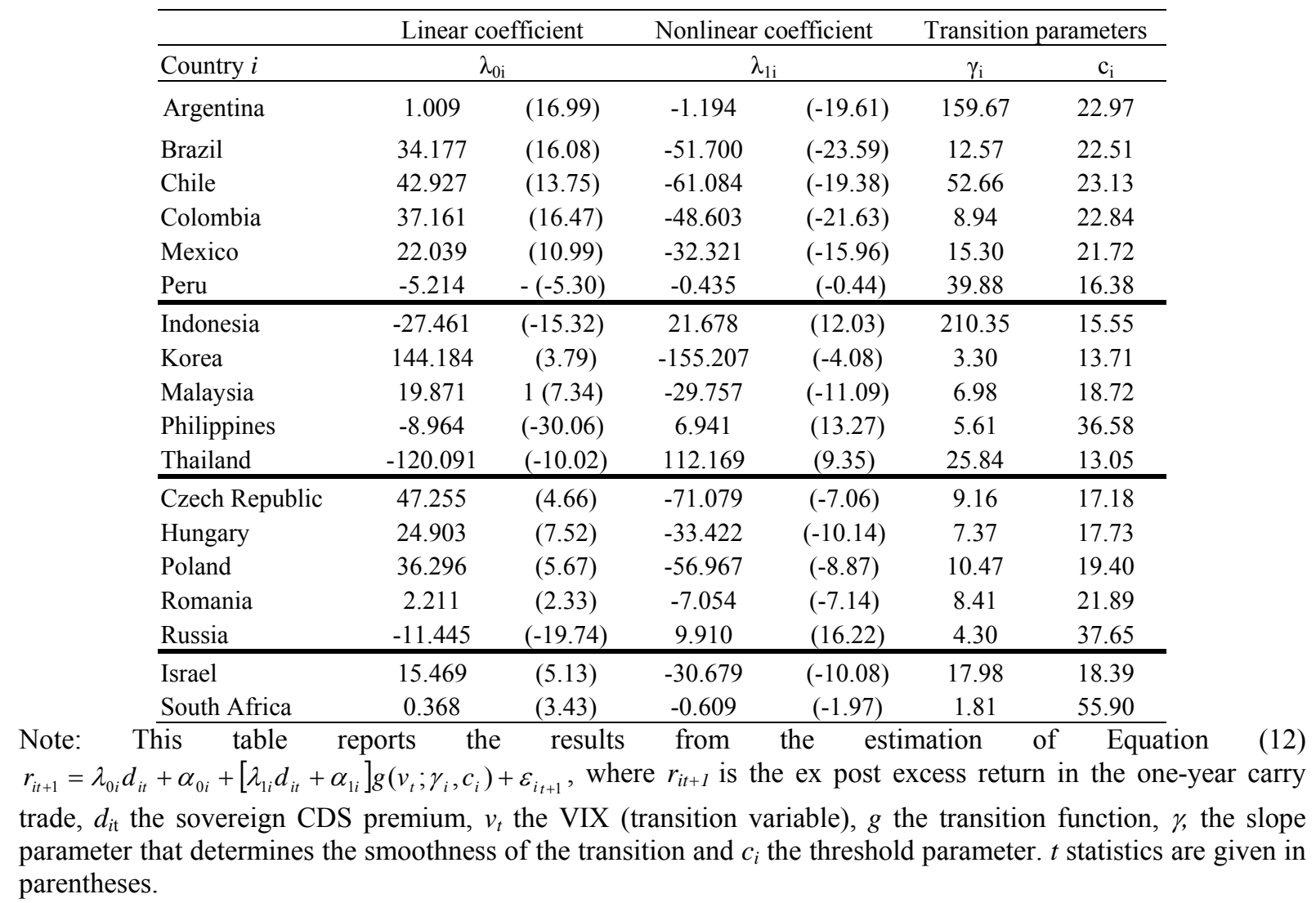

To display more synthetic results, we run panel estimations relying on the panel smooth transition regression (PSTR) model introduced by González et al. (2005). Following the methodology used in the time series context, the authors suggest a three-step strategy to apply PSTR models. In the first, specification step, we test for homogeneity against the PSTR alternative, using the LM-test statistic provided by González et al. (2005). In the second, estimation step, nonlinear least squares are used to obtain the parameter estimates, once the data have been demeaned. Finally, in the evaluation step, we apply misspecification tests in order to check the validity of the estimated PSTR model. ${ }^{6}$

Results obtained through the PSTR model comfort our previous findings (Table 4). First, when the level of volatility is low, the default risk contributes to swell the carry-trade gains. This is attested by the significantly coefficient $\lambda_{0 \mathrm{i}}$, for the whole sample, as well as for Latin America and emerging Europe, Asia being an exception. Second, when the volatility overcomes a certain threshold, the coefficient sign changes, and the default risk contributes to

\footnotetext{
${ }^{6}$ We follow González et al. (2005) who propose to adapt the tests of parameter constancy over time and of no remaining nonlinearity introduced by Eitrheim and Teräsvirta (1996) in the time series context. All the test results are available upon request to the authors.
} 
deepen the losses. This is shown by the negative value of coefficient $\lambda_{1 i}$, with a higher absolute value than $\lambda_{0 \mathrm{i}}$ for all panels.

Third, the level of the VIX which determines the transition between the two regimes is estimated around $23 \%$ for all the panels. In other words, the relation between carry-trade gains and CDS premia starts to be reversed when the VIX crosses the value of $23 \%$. This figure roughly fits our definition of periods given in Section 3, as the crisis is identified when the VIX suddenly jumps above its former level of $25 \%$ and ends when it gets back to this value. During the 2008-2009 crisis, as the VIX has suddenly jumped from a value of $25 \%$ to nearly $80 \%$ in a few days, the transition between the two regimes has been very brutal.

Table 4. Coefficient $\lambda_{i}$ in the nonlinear estimations (panel)

\begin{tabular}{lcccc}
\hline & Linear & \multicolumn{2}{c}{ Nonlinear } & \multicolumn{2}{c}{ Transition parameters } \\
\hline Panel $i$ & $\lambda_{0 \mathrm{i}}$ & $\lambda_{1 \mathrm{i}}$ & $\gamma_{\mathrm{i}}$ & $\mathrm{c}_{\mathrm{i}}$ \\
\hline Whole sample & $\begin{array}{c}1.926 \\
(15.802)\end{array}$ & $\begin{array}{c}-2.673 \\
(-22.677)\end{array}$ & 6.784 & 23.009 \\
\hline Latin America & $\begin{array}{c}1.464 \\
(20.627)\end{array}$ & $\begin{array}{c}-1.707 \\
(-24.564)\end{array}$ & 5.358 & 23.022 \\
\hline Asia & $\begin{array}{c}-3.297 \\
(-6.964)\end{array}$ & $\begin{array}{c}-3.811 \\
(-9.324)\end{array}$ & 2.545 & 23.778 \\
\hline Emerging Europe & $\begin{array}{c}7.651 \\
(15.257)\end{array}$ & $\begin{array}{c}-12.857 \\
(-26.638)\end{array}$ & 1.219 & 21.499 \\
\hline
\end{tabular}

Note: see Table 3.

\section{REVISITING THE FAMA REGRESSION}

As interest rates are highly correlated with default risk, we have to verify whether our results persist if the regression also included the interest-rate differential. To do so, we first run the "Fama regression", which links the exchange-rate change to the interest differential, and then introduce in it the default risk.

\subsection{The standard Fama regression}

The existence of a forward bias is generally evidenced by estimating a regression between the realized exchange-rate change and the interest-rate differential (Chaboud and Wright, 2005; Chinn, 2006; Clarida et al., 2009). The regression between the two variables is referred to as the "Fama regression" and expressed as followed:

$$
s_{i t+1}-s_{i t}=\beta_{i}\left(i_{i t}-i_{t}^{U S}\right)+\alpha_{i}+\varepsilon_{i t+1}
$$


where $s_{i t+1}-s_{i t}$ stands for the one-year change in country's $i$ exchange rate versus dollar (in logarithms), $\left(i_{i_{t}}-i_{t}^{U S}\right)$ the one-year interest-rate differential between country $i$ and the US; $\beta_{i}$ and $\alpha_{i}$ being parameters to estimate.

If there were no forward bias, the estimation of Equation (15) would give $\beta_{i}=1$ and $\alpha_{i}=0$. However, as previous literature has shown, ${ }^{7} \beta_{i}$ is often found smaller than 1 , or even negative. More precisely, Brunnermeier and Pedersen (2009) have shown that the $\beta_{i}$ are smaller than 1 during periods of low volatility, and switch to strong positive values during crises.

The estimations made on our sample of 18 currencies confirm those previous results (Table A.3 in the Appendix). They are also consistent with the panel estimations reported in Table 5: the $\beta_{i}$ are significantly negative for all panels during the tranquil periods and significantly greater than unity during the crisis.

Figure 4 illustrates these changes in the value of $\beta$ across periods for Mexico. The regression line between the interest-rate differential and the currency depreciation has a negative slope in the upbeat market period as well as during the recovery. Conversely, the slope turned positive during the crisis.

\section{Table 5. Coefficient $\beta_{i}$ in the Fama regression (panel estimation)}

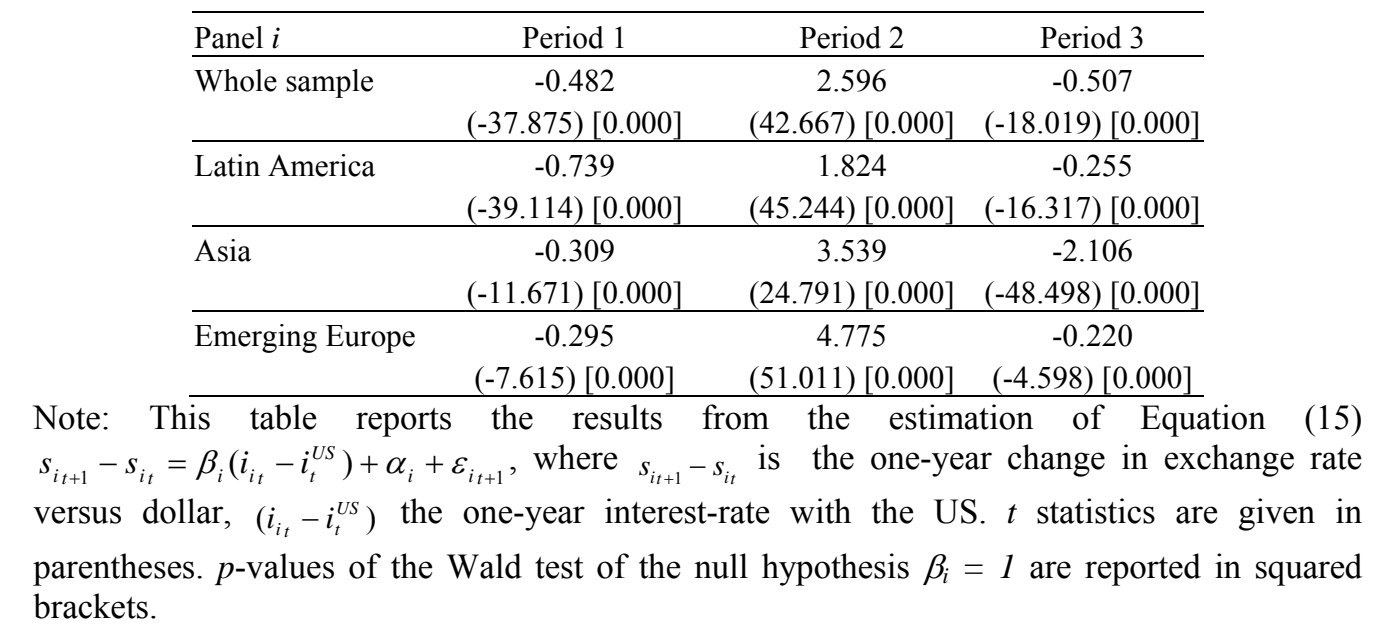

\footnotetext{
${ }^{7}$ See Engel (1995) for a survey.
} 
Figure 4. Interest-rate differential and change in the exchange rate, regression lines across the three sub-periods, Mexico

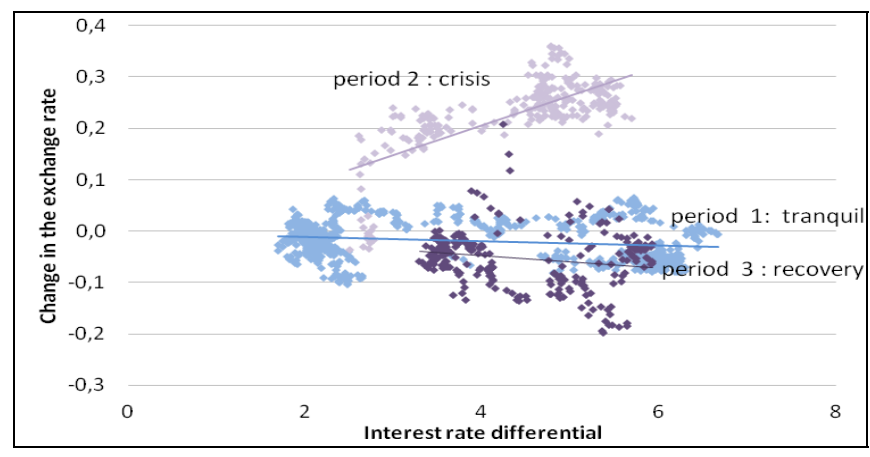

\subsection{Introducing the default risk into the Fama regression}

To verify the hypothesis that the default risk explains the forward bias at least partly, we now introduce the default risk proxy into the Fama regression. This "augmented Fama regression" is written as follows:

$s_{i t+1}-s_{i t}=\beta_{i}^{\prime}\left(i_{i t}-i_{t}^{U S}\right)+\alpha_{i}^{\prime}+\lambda_{i} d_{i t}+\varepsilon_{i t+1}$

Note that the term captured in the Fama regression if the coefficient $\beta_{\mathrm{i}}$ was unity, $s_{i t+1}-s_{i t}-\left(i_{i t}-i_{t}^{U S}\right)$, is the opposite of the ex post excess return in the carry trade. To be consistent with propositions (P1) and (P2) stated above, we therefore expect to find $\lambda_{i}$ negative during tranquil periods, and positive during the crisis.

To comfort our hypothesis, we would also require that the bias found in the coefficient $\beta_{i}$ estimated in the former section is reduced. We therefore expect the $\beta_{i}$ ' estimated during the low volatility periods to be greater than the corresponding coefficient $\beta_{\mathrm{i}}$ estimated over the same period in Equation (15), that do not take into account the default risk.

The estimation results match our expectations, lending support to our hypothesis. Results on a country-by-country basis for the three considered sub-periods are reported in the Appendix (Table A.4). Firstly, the coefficient on the default risk $\lambda_{i}$ is negative as expected in the first period for most currencies (15 in 18). This means that default risk reduces the depreciation in the currency during the upbeat market period and contributes to the forward premium. Secondly, the coefficient turns positive during the crisis for 16 currencies out of 18 , as the default risk accentuates the depreciation of the currency during the turmoil. Thirdly, the coefficient on the interest-rate differential $\beta_{\mathrm{i}}$ ' is found higher than its counterpart in Equation (15) for the majority of countries (12 out of 18) in the tranquil period, as expected. 
These results are confirmed by the panel estimations (Table 6). First, the coefficient on the risk default proxy $\lambda_{\mathrm{i}}$ is negative as expected in the first period for all the considered areas. Second, its value increases during the crisis for all panels, and even switches to positive territories for Asia and emerging Europe. Third, the coefficient on the interest-rate differential $\beta_{i}{ }^{\prime}$ in the first period is higher than the same coefficient estimated in Equation (15) for all the considered panels. Moreover, the coefficients $\beta_{\mathrm{i}}$ ' are now positive for the first period for two areas: Asia and emerging Europe, whereas they were negative for all panels in the standard Fama regression. Consequently, the bias on this coefficient when estimated over a period of upbeat markets, which evidences the existence of a "forward bias", is mitigated by taking into account the default risk.

Table 6. Results of the “augmented Fama regression” (panel estimation)

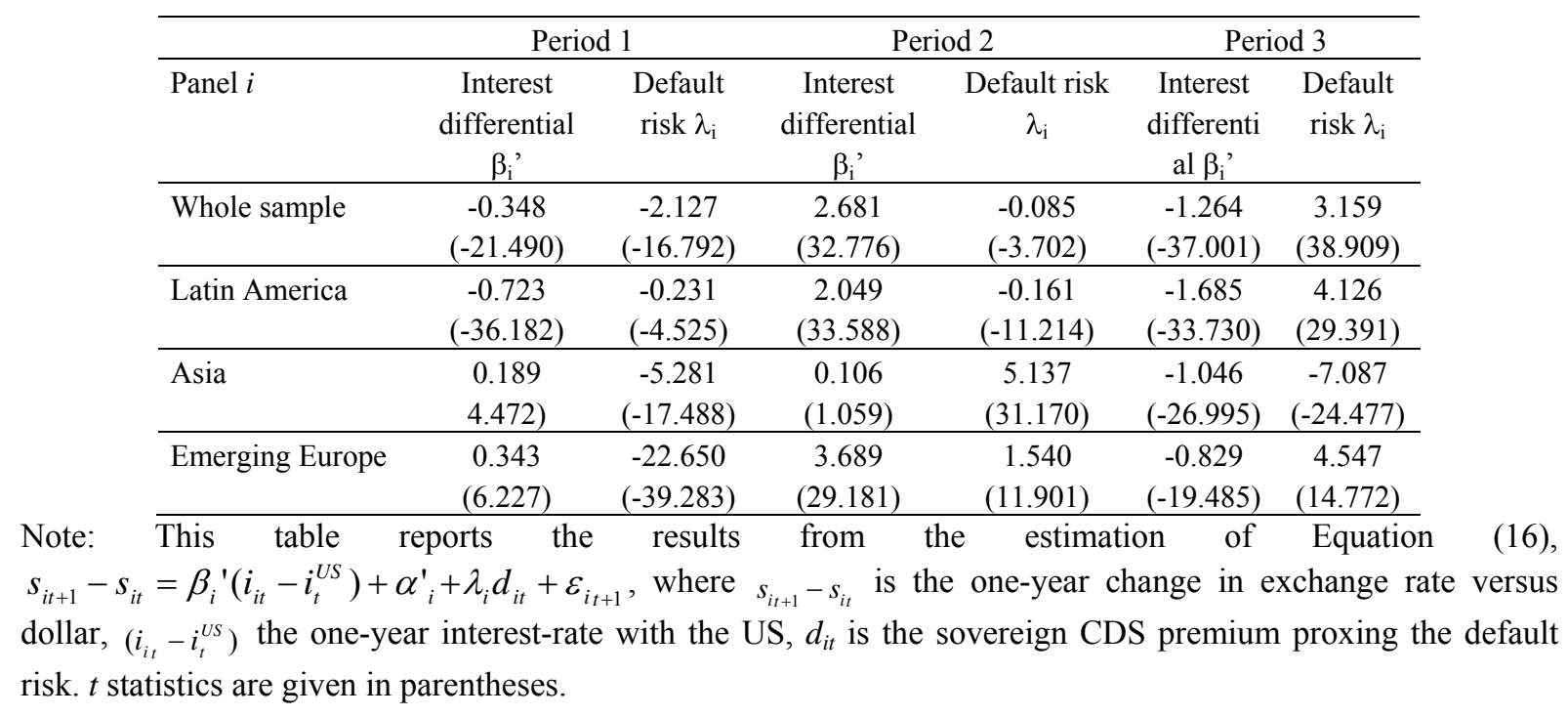

\subsection{Evidencing the nonlinearities in the Fama regression}

On the whole, our findings clearly highlight a reversal in the relationship between the exchange-rate change and the interest-rate differential across periods, whether the default risk is introduced or not. The coefficients $\beta_{i}$ are suddenly shifted upwards during the crises, along with the coefficient $\lambda_{i}$ on the default risk.

This leads us to test for nonlinearities in the Fama regression, by using a STR specification. The exchange-rate change now depends nonlinearly on the interest differential, their relationship fluctuating according to the evolution of market volatility. More specifically, the STR model is given by:

$s_{i t+1}-s_{i t}=\beta_{0 i}\left(i_{i t}-i_{t}^{U S}\right)+\alpha_{0 i}+\left|\beta_{1 i}\left(i_{i t}-i_{t}^{U S}\right)+\alpha_{1 i}\right| g\left(v_{t} ; \gamma_{i}, c_{i}\right)+\varepsilon_{i t+1}$ 
The null hypothesis of linearity being rejected in favour of the LSTR specification, the exchange rate responds differently to the interest differential according to market volatility. More specifically, as for the estimation of Equation (12), there are two regimes involved: the first one prevails when the volatility is low on financial markets, and the second one intervenes when financial markets are nervous - the VIX exceeding a certain threshold.

Several findings stand out from the results (Table 7). First, the coefficient $\beta_{0 \mathrm{i}}$ of the interestrate differential is lower than one for the majority of countries, and even negative for 10 countries in the low-volatility regime. This illustrates the fact that high-yield currencies tend to appreciate under low-volatility environment. Second, the coefficient sharply rises with the financial markets jitteriness, i.e. when the value of the VIX exceeds a certain threshold $c$, as $\beta_{1 i}$ is positive and greater than 1 in the high-volatility regime for all currencies (except for the Russian rouble). In other words, the "forward bias" disappears in high-volatility periods. Third, the threshold value of the VIX that triggers the nonlinear regime is above $25 \%$ for all currencies, matching the previous conclusions. Results obtained on a panel basis confirm the previous findings: the coefficient on the interest-rate differential is lower than 1 -and even negative for two groups of countries - in the low-volatility regime, while it is always greater than unity when the VIX exceeds its threshold.

Table 7. Results of the non-linear estimations of the Fama regression

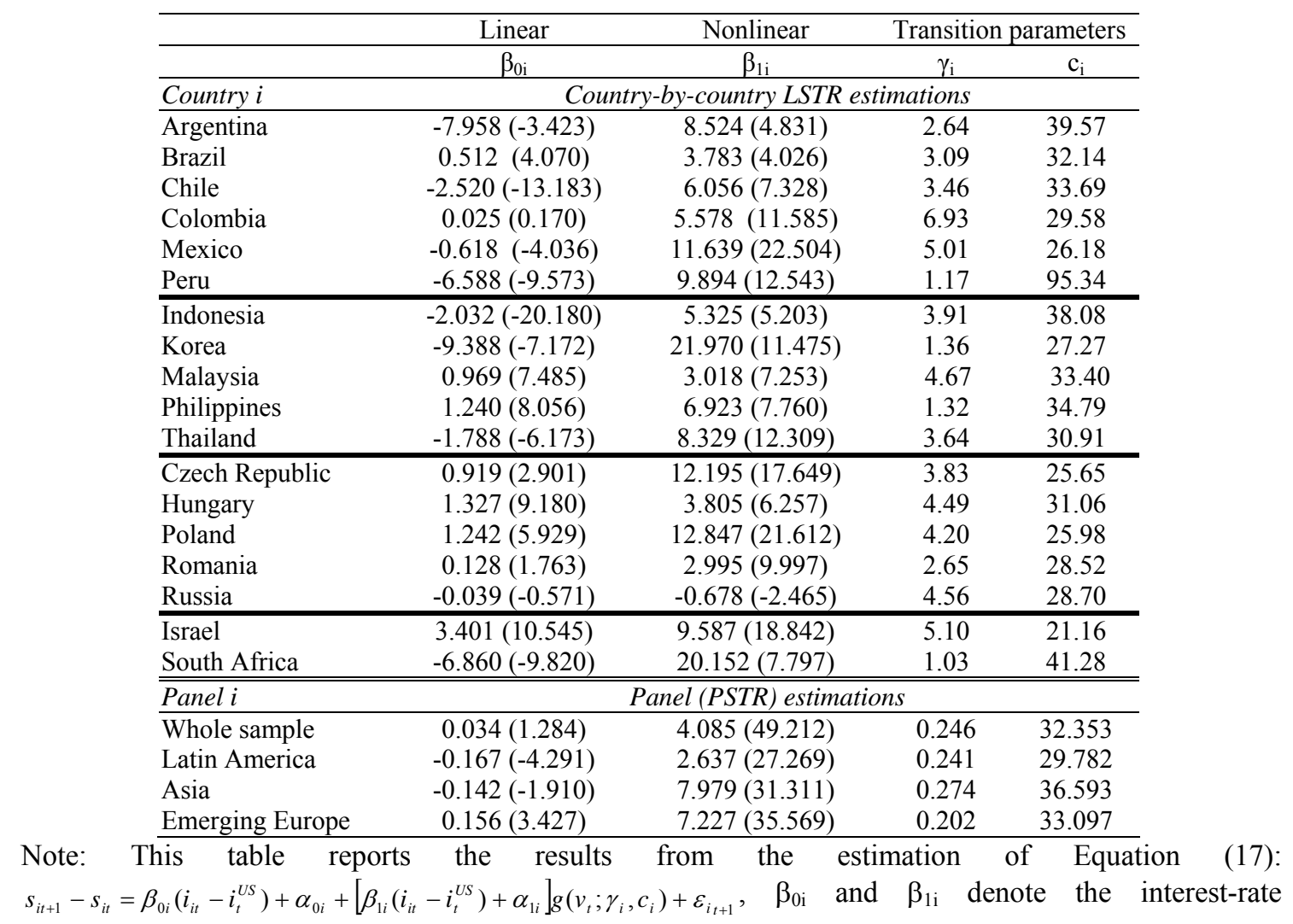


differential coefficients in the linear and nonlinear regimes, respectively. $\gamma_{i}$ is the slope parameter and $c_{i}$ is the threshold value of the VIX (in \%). $t$ statistics are given in parentheses.

\subsection{Nonlinearities in the "augmented" Fama regression}

Our "augmented Fama regression", including the default risk and expressed in Equation (16) is also likely to exhibit strong nonlinearities for two reasons: (i) the coefficient $\beta$ varies across periods, on the same grounds as in the Fama regression, and (ii) default risk tends to boost carry-trade gains when markets are upbeat, and to worsen the losses in financial turmoil as shown in Section 4.2; therefore the coefficient $\lambda$ also fluctuates according to the mood in financial markets.

To check that, we estimate the STR following model, where the transition from one state to the other is governed by the level of the VIX:

$$
s_{i t+1}-s_{i t}=\beta_{0 i}\left(i_{i t}-i_{t}^{U S}\right)+\lambda_{0 i} d_{i t}+\alpha_{0 i}+\left[\beta_{1 i}\left(i_{i t}-i_{t}^{U S}\right)+\lambda_{1 i} d_{i t}+\alpha_{1 i}\right] g\left(v_{t} ; \gamma_{i}, c_{i}\right)+\varepsilon_{i t+1}
$$

Results of the tests confirm both the existence of nonlinearities and the logistic form of the transition function $g$. Estimations reported in Table 8 give support to our hypothesis about the role of the default risk in the forward bias. First, when markets are upbeat, the default risk hinders the exchange-rate depreciation in the majority of cases (as $\lambda_{0 \mathrm{i}}$ is significantly negative for 9 currencies in 17). Second, when markets become nervous, the depreciation in the exchange rate is accentuated by the default risk (as $\lambda_{1 \mathrm{i}}$ is significantly positive in 11 cases out of 17).

Table 8. Results of the non-linear estimations of the "augmented Fama regression"

\begin{tabular}{|c|c|c|c|c|c|c|}
\hline \multicolumn{3}{|c|}{ Linear } & \multirow{2}{*}{$\begin{array}{c}\text { Nonlinear } \\
\beta_{1 \mathrm{i}} \\
\end{array}$} & \multirow{2}{*}{$\begin{array}{c}\text { Nonlinear } \\
\lambda_{1 \mathrm{i}}\end{array}$} & \multicolumn{2}{|c|}{$\begin{array}{l}\text { Transition } \\
\text { parameters }\end{array}$} \\
\hline Country $i$ & $\beta_{0 \mathrm{i}}$ & $\lambda_{0 \mathrm{i}}$ & & & $\gamma_{\mathrm{i}}$ & $\mathrm{c}_{\mathrm{i}}$ \\
\hline Brazil & $0.069(0.612)$ & $-34.661(-17.126)$ & $2.202(5.429)$ & $52.809(25.320)$ & 18.682 & 23.034 \\
\hline Chile & $-8.600(-4.651)$ & $-83.374(-2.022)$ & $7.192(3.793)$ & $104.140(2.529)$ & 3.933 & 13.154 \\
\hline Colombia & $1.293(7.675)$ & $-38.390(-15.3$ & 1.465( & 47.792( & 7.773 & 23.492 \\
\hline Mexi & $-0.563(-$ & -18.966 & 5.264( & 26.886 & 12.714 & 22.354 \\
\hline Peru & $-6.507(-8.999)$ & $6.642(7$. & $9.614(13.027)$ & -2.559( & 15.864 & 17.128 \\
\hline Korea & $-6.559(-15.667)$ & 9574 & 5.898 & 3.046 & 10.087 & 22.651 \\
\hline Indor & $-0.349(-2.091)$ & 19.438 & $-2.048(-1$ & -14.675 & 212.49 & 15.551 \\
\hline Malaysia & $1.998(7.625)$ & $-28.946(-6.547)$ & $-0.839(-2.672)$ & $38.690(8.809)$ & 7.203 & 17.807 \\
\hline Philippines & $1.398(20.237)$ & 9.599 & $-0.871(-1.914)$ & $-7.393(-14.963)$ & 6.143 & 36.502 \\
\hline Thailand & $-12.657(-15.037)$ & $63.537(7.574)$ & $12.901(14.954)$ & $-55.217(-6.579)$ & 20.364 & 13.415 \\
\hline Czech Re & $2.092(6.899)$ & $-59.567(-8.864)$ & $4.933(9.301)$ & $71645(10$ & 5.283 & 19.707 \\
\hline Hung & 1.25 & & -0.697( & 32.404 & 8.137 & 17.800 \\
\hline Poland & $0.899(4.176)$ & & $7.220(16.279)$ & $55.927(10.793)$ & 5.648 & 19.679 \\
\hline Romania & $-0.142(-2.890)$ & $7.667(29.070)$ & $2.045(7.105)$ & $-6.532(-12.924)$ & 5.070 & 33.855 \\
\hline Russia & $-0.509(-10.648)$ & $15.374(31.536)$ & $3.264(7.564)$ & $-13.082(-24.374)$ & 6.251 & 36.481 \\
\hline & 31200 & & & & & 17.817 \\
\hline No & $-4.805(-19.154)$ & $-8.572(-5.129)$ & $2.256(6.814)$ & $20.548(12.034)$ & 76.831 & 23.075 \\
\hline
\end{tabular}

Note: This table reports the results from the estimation of Equation (18)

$s_{i t+1}-s_{i t}=\beta_{0 i}\left(i_{i t}-i_{t}^{U S}\right)+\lambda_{0 i} d_{i t}+\alpha_{0 i}+\left[\beta_{1 i}\left(i_{i t}-i_{t}^{U S}\right)+\lambda_{1 i} d_{i t}+\alpha_{1 i}\right] g\left(v_{t} ; \gamma_{i}, c_{i}\right)+\varepsilon_{i t+1}, \beta_{0 \mathrm{i}}$ and $\beta_{1 \mathrm{i}}$ denote the interest-rate 
differential coefficients in the linear and nonlinear regimes, $\lambda_{0 \mathrm{i}}$ and $\lambda_{1 \mathrm{i}}$ the CDS premia coefficients in the linear and nonlinear regimes, respectively. $\gamma_{i}$ is the slope parameter and $c_{i}$ is the threshold value of the VIX (in \%). The model does not converge for Argentina. $t$ statistics are given in parentheses.

\section{CONCLUSION}

The positive excess returns on carry trades invested in high-yield currencies has long constituted a famous puzzle for economists and paved the way for an extensive literature. Here, we state the hypothesis that carry-trade gains observed in upbeat markets can be construed as a risk premium stemming both from exchange rate and default risk. If this hypothesis holds, two propositions should follow: (i) currencies issued by a country with a high default risk should yield higher excess returns when financial market are buoyant ; (ii) conversely, these currencies depreciate more severely during crises - the riskier the country in terms of default, the sharper the reversal of carry-trade gains during crises.

We have verified these propositions empirically on a sample of 18 emerging currencies by two means. First, we run a linear regression between carry-trade gains and a proxy of the default risk. We obtain the expected signs on the coefficients when splitting the estimations into different sub-periods corresponding to bull markets and crisis. Then we run a nonlinear regression where the impact of the default risk on carry-trade gains changes according to market volatility. This allows us to confirm the two propositions above: (i) when market volatility is low, carry-trade gains are boosted by default risk; (ii) over a certain threshold, the more volatile the financial markets become, the deeper the losses on investment in high default risk countries.

As carry-trade gains are also correlated with interest-rate differentials, we had to verify that the former results are still valid when accounting for interest differentials. To do that, we use the so-called "Fama regression", linking the exchange-rate change to the interest differential, in which we add the default risk proxy. Interestingly, the default risk remains significant with the expected sign switching across periods. Moreover, the "forward bias", usually evidenced by a coefficient smaller than unity in this regression during tranquil periods, is somewhat mitigated, as the default risk partially explains the excess return.

On the whole, our findings give support to the hypothesis that default risk contributes to fuel excess returns in the exchange market during periods of upbeat markets. However, we are aware that this factor only partially explains the forward bias. First, by taking into account the default risk, the coefficient that links the exchange-rate depreciation to the interest-rate differential in the Fama regression gets closer to unity, but still stays smaller than one. This leaves room for an unexplained part in the forward bias. Second, many carry trades are invested in advanced country currencies, such as the Australian or the New Zealand dollar, with practically no sovereign default risk. Hence, the present results only show that the default risk contributes to increase the forward bias in the case of risky emerging countries. 


\section{REFERENCES}

Becker, R., Clements, A. and A. McClelland (2009), "The Jump Component of S\&P 500 Volatility and the VIX Index", Journal of Banking and Finance 33(6), 1033-1038.

Brunnermeier, M., Nagel, S. and L. Pedersen (2008), "Carry trades and currency crashes", NBER Working Paper 14473.

Brunnermeier, M. K. and L. H. Pedersen (2009), "Market Liquidity and Funding Liquidity", Review of Financial Studies 22(6), 2201-2238.

Burnside, A., Eichenbaum, M., Kleshchelski, I. and S. Rebelo (2008), "Do peso problems explain the returns to the carry trade?”, NBER Working Paper 14054.

Chaboud, A. P. and J.H. Wright (2005), "Uncovered interest parity: it works, but not for long”, Journal of International Economics 66, 349-362.

Chinn, M. (2006), "The (partial) rehabilitation of interest rate parity in the floating rate era: Longer horizons, alternative expectations, and emerging markets", Journal of International Money and Finance 25.

Clarida, R., Davis, J. and N. Pedersen (2009), "Currency Carry Trade Regimes: Beyond the Fama Regression”, NBER Working Paper 15523.

Cochrane, J. (2001), Asset Pricing, Princeton University Press, Princeton, New Jersey.

Coudert, V., Couharde, C. and V. Mignon (2011), "Exchange rate Volatility across Financial Turmoil", Journal of Banking and Finance, forthcoming.

Coudert, V., Gex, M. (2008), "Does Risk Aversion Drive Financial Crises? Testing the Predictive Power of Empirical Indicators", Journal of Empirical Finance 15(2).

Eitrheim, O. and T. Teräsvirta (1996), "Testing the Adequacy of Smooth Transition Autoregressive Models", Journal of Econometrics 74, 59-76.

Engle, R.F. (1982), “Autoregressive Conditional Heteroscedasticity with Estimates of the Variance of United Kingdom Inflation”, Econometrica 50(4), 987-1007.

Engel, C. (1995), "The forward discount and the risk premium anomaly: survey of recent evidence”, NBER Working Paper 5312.

Fama, E.F. (1984), "Forward and Spot Exchange Rates", Journal of Monetary Economics 14, 319-38.

Frankel, J.A. (1973), "Elasticities and the Interest Parity Theory", Journal of Political Economy 81(3), 741-747.

Huisman, R., Koedijk, K., Kool, C. and F. Nissen (1998), "Extreme Support for Uncovered Interest Parity", Journal of International Money and Finance 17(1), 211-28. 
Galati, G., Heath, A. and P. McGuire (2007), "Evidence of Carry Trade Activity", BIS Quarterly Review, September, 27-41.

González, A., Teräsvirta, T. and D. van Dijk (2005), "Panel Smooth Transition regression models", Research Paper 165, Quantitative Finance Research Centre, University of Technology, Sidney.

Kohler, M. (2010), "Exchange rate during Financial Crises”, BIS Quarterly Review, March.

Liu, F. and P. Sercu (2009), "The Forex Forward Puzzle: The Career Risk Hypothesis”, The Financial Review.

Lustig, H. and A. Verdelhan (2007), "The Cross-Section of Foreign Currency Risk Premia and US Consumption Growth Risk”, American Economic Review 97(1), 89-117.

Mark, N.C. (2001), International Macroeconomics and Finance, Blackwell Publishers.

McCauley, R. and P. McGuire (2009), "Dollar Appreciation in 2008: safe haven, carry trades, dollar shortage and overhedging”, BIS Quarterly Review, December.

Meese, R. A. and K. Rogoff. (1983), "Empirical Exchange Rate Models of the Seventies: Do They Fit Out of Sample?" Journal of International Economics 14, 3-24.

Mehra, R. and E. Prescott (1985), "The equity premium: a puzzle", Journal of Monetary Economics 15, 145-161.

Mehra, R. and E. Prescott (2003), "The Equity Premium Puzzle in Retrospect", In G.M. Constantinides, M. Harris and R. Stulz (eds), Handbook of the Economics of Finance, Amsterdam: North Holland, 889-938.

Newey, W.K. and K.D. West (1987), “A Simple, Positive Semi-definite, Heteroskedasticity and Autocorrelation Consistent Covariance Matrix", Econometrica 55(3), 703-708.

Ranaldo, A. and P. Söderlind (2007), "Safe Haven Currencies", Economics Discussion Paper no. 2007-22, University of St. Gallen.

Teräsvirta, T. (1994), "Specification, Estimation, and Evaluation of Smooth Transition Autoregressive Models", Journal of the American Statistical Association 89, 208-218.

Teräsvirta, T. (1998), "Modeling economic relationships with smooth transition regressions", in A. Ullah and D. Giles (eds), Handbook of Applied Economic Statistics, Dekker, New York, 229-246.

Teräsvirta, T. and H.M. Anderson (1992), "Characterizing Nonlinearities in Business Cycles Using Smooth Transition Autoregressive Models", Journal of Applied Econometrics 7(S), S119-36.

Tong, H. (1990), Non-linear Time Series. A Dynamical System Approach, Oxford University Press.

Verdelhan A. (2010), “A Habit-Based Explanation of the Exchange Rate Risk Premium”, Journal of Finance LXV(1). 


\section{APPENDIX}

Table A.1. Average sovereign CDS premium by country and period, in basis points

\begin{tabular}{|c|c|c|c|}
\hline & $\begin{array}{c}\text { Period } 1 \\
\text { Tranquil } \\
06 / 01 / 2005 \text { to } \\
09 / 12 / 2008 \\
\end{array}$ & $\begin{array}{c}\text { Period } 2 \\
\text { Crisis } \\
09 / 12 / 2008 \text { to } \\
09 / 30 / 2009 \\
\end{array}$ & $\begin{array}{c}\text { Period } 3 \\
\text { Recovery } \\
10 / 01 / 2009 \text { to } \\
09 / 30 / 2010 \\
\end{array}$ \\
\hline Argentina & 160.4 & 3224 & 869.5 \\
\hline Brazil & 36.7 & 170.8 & 68 \\
\hline Chile & 9.6 & 124.7 & 31.7 \\
\hline Colombia & 42.1 & 202.7 & 79.4 \\
\hline Mexico & 21.8 & 202.4 & 75.9 \\
\hline Peru & 39.6 & 183.6 & 68.3 \\
\hline Korea & 20.1 & 245.4 & 69.8 \\
\hline Indonesia & 65.8 & 384.8 & 97.4 \\
\hline Malaysia & 18.9 & 136.1 & 36.2 \\
\hline Philippines & 72.2 & 267.2 & 94.1 \\
\hline Thailand & 21.3 & 147 & 67.2 \\
\hline Czech Rep. & 5.3 & 98.7 & 48.4 \\
\hline Hungary & 16.3 & 347.4 & 195.8 \\
\hline Poland & 8.7 & 162.9 & 69.8 \\
\hline Romania & 23.1 & 420.7 & 226.3 \\
\hline Russia & 37.4 & 534.9 & 86.4 \\
\hline Israel & 12.7 & 117.8 & 59 \\
\hline South Africa & 25.2 & 247.2 & 78.5 \\
\hline Average & 35.4 & 401.0 & 129.0 \\
\hline
\end{tabular}


Table A.2. Coefficient $\lambda_{i}$ in the linear estimations (country-by-country)

\begin{tabular}{lccc}
\hline Country $i$ & Period 1 & Period 2 & Period 3 \\
\hline Argentina & $1.634(16.261)$ & $-0.0463(-2.463)$ & $1.332(21.794)$ \\
Brazil & $65.473(37.156)$ & $-7.509(-15.577)$ & $39.011(15.317)$ \\
Chile & $20.661(4.619)$ & $-15.514(-24.715)$ & $27.470(6.884)$ \\
Colombia & $25.131(24.044)$ & $-5.150(-10.769)$ & $25.947(20.453)$ \\
Mexico & $23.846(13.649)$ & $-8.284(-23.102)$ & $11.750(9.531)$ \\
Peru & $8.995(7.533)$ & $-1.833(-8.614)$ & $10.904(18.721)$ \\
\hline Indonesia & $4.950(6.245)$ & $-2.602(-14.682)$ & $23.817(24.776)$ \\
Korea & $-4.217(-1.838)$ & $-10.376(-29.924)$ & $19.348(10.414)$ \\
Malaysia & $10.068(7.858)$ & $-5.293(-15.783)$ & $20.823(10.393)$ \\
Philippines & $12.131(14.648)$ & $-3.066(-22.464)$ & $7.141(17.079)$ \\
Thailand & $17.348(8.009)$ & $-3.180(-9.044)$ & $9.356(18.117)$ \\
\hline Czech Republic & $142.568(18.014)$ & $-12.496(-13.578)$ & $5.301(1.761)$ \\
Hungary & $37.295(11.372)$ & $-4.451(-19.259)$ & $1.801(1.942)$ \\
Poland & $112.518(21.255)$ & $-13.819(-16.480)$ & $8.984(4.214)$ \\
Romania & $21.327(6.721)$ & $-3.661(-20.488)$ & $2.773(3.874)$ \\
Russia & $17.601(22.011)$ & $-2.599(-8.607)$ & $18.538(11.058)$ \\
\hline Israel & $55.019(17.147)$ & $-6.076(-7.841)$ & $7.462(8.049)$ \\
South Africa & $-3.753(-3.315)$ & $-5.177(-9.249)$ & $30.072(12.325)$ \\
\hline Note: This table reports the results from the estimation of Equation $(11): r_{i t+1}=\lambda_{i} d_{i t}+\alpha_{i}+\varepsilon_{i t+1}$ where $r_{i t+1}$ is \\
the ex post excess return in the one-year carry trade invested at time $t$ in currency $i$ and $d_{i t}$ is country $i$ s \\
sovereign CDS premium. $t$ statistics are given in parentheses. &
\end{tabular}


Table A.3. Coefficient $\beta_{i}$ in the Fama regression (country-by-country)

\begin{tabular}{|c|c|c|c|}
\hline Country $i$ & Period 1 & Period 2 & Period 3 \\
\hline \multirow{2}{*}{ Argentina } & 0.209 & 1.275 & 0.381 \\
\hline & (3.879) [0.000] & $(19.826)[0.000]$ & $(14.665)[0.000]$ \\
\hline \multirow[b]{2}{*}{ Brazil } & -1.144 & 2.433 & -2.065 \\
\hline & $(-17.610)[0.000]$ & $(12.047)[0.000]$ & $(-21.715)[0.000]$ \\
\hline \multirow{2}{*}{ Chile } & 1.327 & -5.766 & 7.342 \\
\hline & (9.491) [0.019] & $(-11.698)[0.000]$ & $(10.729)[0.000]$ \\
\hline \multirow{2}{*}{ Colombia } & -1.698 & 2.681 & -2.414 \\
\hline & $(-9.860)[0.000]$ & (9.404) [0.000] & $(-15.393)[0.000]$ \\
\hline \multirow{2}{*}{ Mexico } & -0.479 & 5.216 & -1.209 \\
\hline & $(-5.556)[0.000]$ & $(38.815)[0.000]$ & $(-7.176)[0.000]$ \\
\hline \multirow{2}{*}{ Peru } & -9.082 & 2.487 & -3.650 \\
\hline & $(-6.245)[0.000]$ & $(12.402)[0.000]$ & $(-3.418)[0.000]$ \\
\hline \multirow{2}{*}{ Indonesia } & -0.148 & 2.262 & -1.863 \\
\hline & $(-1.759)[0.000]$ & $(9.295)[0.000]$ & $(-20.094)[0.000]$ \\
\hline \multirow{2}{*}{ Korea } & -2.927 & 10.038 & -4.689 \\
\hline & $(-2.684)[0.000]$ & $(11.133)[0.000]$ & $(-12.396)[0.000]$ \\
\hline \multirow{2}{*}{ Malaysia } & 3.656 & 4.602 & -8.381 \\
\hline & $(27.748)[0.000]$ & (3.031) [0.018] & $(-7.504)[0.000]$ \\
\hline \multirow{2}{*}{ Philippines } & -1.207 & 3.714 & -1.776 \\
\hline & $(-8.269)[0.000]$ & $(12.600)[0.000]$ & $(-16.466)[0.000]$ \\
\hline \multirow{2}{*}{ Thailand } & 2.321 & 3.136 & -5.593 \\
\hline & (3.619) [0.039] & (3.241) [0.027] & (-7.973) 0.000$]$ \\
\hline \multirow{2}{*}{ Czech Republic } & 5.339 & 14.461 & -2.497 \\
\hline & $(14.381)[0.000]$ & $(16.559)[0.000]$ & $(-2.306)[0.001]$ \\
\hline \multirow{2}{*}{ Hungary } & -0.320 & 4.369 & -0.237 \\
\hline & $(-1.505)[0.000]$ & $(23.462)[0.000]$ & $(-0.992)[0.000]$ \\
\hline \multirow{2}{*}{ Poland } & 0.380 & 10.500 & -1.102 \\
\hline & $(0.915)$ [0.135] & $(30.450)[0.000]$ & $(-2.650)[0.000]$ \\
\hline \multirow{2}{*}{ Romania } & -0.751 & 3.286 & 0.055 \\
\hline & $(-6.884)[0.000]$ & $(18.515)[0.000]$ & $(0.525)[0.000]$ \\
\hline \multirow{2}{*}{ Russia } & -0.917 & 6.069 & -0.327 \\
\hline & $(-7.398)[0.000]$ & $(20.964)[0.000]$ & $(-3.962)[0.000]$ \\
\hline \multirow{2}{*}{ Israel } & 1.730 & 7.686 & 5.142 \\
\hline & (3.538) [0.136] & $(11.293)[0.000]$ & (3.228) [0.009] \\
\hline \multirow{2}{*}{ South Africa } & 1.109 & 1.824 & -2.615 \\
\hline & $(7.817)[0.441]$ & $(6.711)[0.002]$ & $(-13.987)[0.000]$ \\
\hline Note: This $t$ & th & ration (15) $s_{i_{t+1}}-$ & $\beta_{i}\left(i_{i t}-i_{t}^{U S}\right)+\alpha_{i}+\varepsilon_{i t+1}$ \\
\hline
\end{tabular}


Table A.4. Results of the estimation of the Fama regression with the default risk (country-by-country)

\begin{tabular}{|c|c|c|c|c|c|c|}
\hline \multirow[b]{2}{*}{ Country $i$} & \multicolumn{2}{|c|}{ Period 1} & \multicolumn{2}{|c|}{ Period 2} & \multicolumn{2}{|c|}{ Period 3} \\
\hline & $\beta_{\mathrm{i}}^{\prime}$ & $\lambda_{\mathrm{i}}$ & $\beta_{i}^{\prime}$ & $\lambda_{\mathrm{i}}$ & $\beta_{i}{ }^{\prime}$ & $\lambda_{\mathrm{i}}$ \\
\hline Argentina & $\begin{array}{c}0.350 \\
(4.163)\end{array}$ & $\begin{array}{c}-0.482 \\
(-2.813)\end{array}$ & $\begin{array}{c}1.537 \\
(13.959)\end{array}$ & $\begin{array}{c}-0.101 \\
(-3.609)\end{array}$ & $\begin{array}{c}0.485 \\
(5.127)\end{array}$ & $\begin{array}{c}-0.231 \\
(-1.222)\end{array}$ \\
\hline Brazil & $\begin{array}{c}-0.138 \\
(-1.479) \\
\end{array}$ & $\begin{array}{c}-35.261 \\
(-15.007) \\
\end{array}$ & $\begin{array}{c}0.897 \\
(2.970) \\
\end{array}$ & $\begin{array}{c}7.880 \\
(6.349) \\
\end{array}$ & $\begin{array}{c}-4.710 \\
(-18.402) \\
\end{array}$ & $\begin{array}{c}37.209 \\
(10.645) \\
\end{array}$ \\
\hline Chile & $\begin{array}{c}0.416 \\
(2.051) \\
\end{array}$ & $\begin{array}{l}-38.999 \\
(-5.357) \\
\end{array}$ & $\begin{array}{c}-1.285 \\
(-3.470) \\
\end{array}$ & $\begin{array}{c}11.684 \\
(17.349) \\
\end{array}$ & $\begin{array}{c}9.912 \\
(4.538) \\
\end{array}$ & $\begin{array}{r}14.946 \\
(1.559) \\
\end{array}$ \\
\hline Colombia & $\begin{array}{c}0.896 \\
(4.004) \\
\end{array}$ & $\begin{array}{c}-24.530 \\
(-14.834) \\
\end{array}$ & $\begin{array}{c}0.855 \\
(1.776) \\
\end{array}$ & $\begin{array}{c}5.477 \\
(4.914) \\
\end{array}$ & $\begin{array}{c}-1.423 \\
(-2.829) \\
\end{array}$ & $\begin{array}{c}-7.929 \\
(-2.201)\end{array}$ \\
\hline Mexico & $\begin{array}{c}-0.117 \\
(-0.910) \\
\end{array}$ & $\begin{array}{c}-7.860 \\
(-4.227) \\
\end{array}$ & $\begin{array}{c}3.824 \\
(16.950) \\
\end{array}$ & $\begin{array}{r}3.195 \\
(7.698) \\
\end{array}$ & $\begin{array}{c}-3.917 \\
(-5.760) \\
\end{array}$ & $\begin{array}{r}16.313 \\
(4.205) \\
\end{array}$ \\
\hline Peru & $\begin{array}{c}-7.013 \\
(-5.844) \\
\end{array}$ & $\begin{array}{c}-8.236 \\
(-7.876) \\
\end{array}$ & $\begin{array}{c}1.716 \\
(7.219) \\
\end{array}$ & $\begin{array}{c}1.189 \\
(5.746) \\
\end{array}$ & $\begin{array}{c}-0.542 \\
(-1.037)\end{array}$ & $\begin{array}{c}-10.524 \\
(-17.020) \\
\end{array}$ \\
\hline Indonesia & $\begin{array}{c}-0.659 \\
(-7.184)\end{array}$ & $\begin{array}{c}6.015 \\
(7.228) \\
\end{array}$ & $\begin{array}{c}0.244 \\
(1.462)\end{array}$ & $\begin{array}{c}3.428 \\
(10.386) \\
\end{array}$ & $\begin{array}{c}-3.287 \\
(-4.956)\end{array}$ & $\begin{array}{l}12.143 \\
(2.204)\end{array}$ \\
\hline Korea & $\begin{array}{c}-2.599 \\
(-2.077)\end{array}$ & $\begin{array}{c}4.739 \\
(1.986) \\
\end{array}$ & $\begin{array}{c}0.967 \\
(1.567)\end{array}$ & $\begin{array}{c}10.400 \\
(14.741)\end{array}$ & $\begin{array}{c}-2.083 \\
(-1.973)\end{array}$ & $\begin{array}{c}-9.766 \\
(-2.264)\end{array}$ \\
\hline Malaysia & $\begin{array}{c}3.390 \\
(17.498) \\
\end{array}$ & $\begin{array}{c}-1.814 \\
(-1.672) \\
\end{array}$ & $\begin{array}{c}3.396 \\
(9.691) \\
\end{array}$ & $\begin{array}{c}5.117 \\
(24.137) \\
\end{array}$ & $\begin{array}{c}-2.685 \\
(-2.157) \\
\end{array}$ & $\begin{array}{l}-15.679 \\
(-5.734) \\
\end{array}$ \\
\hline Philippines & $\begin{array}{c}0.289 \\
(1.231) \\
\end{array}$ & $\begin{array}{c}-9.344 \\
(-7.285) \\
\end{array}$ & $\begin{array}{c}0.555 \\
(1.909) \\
\end{array}$ & $\begin{array}{c}3.409 \\
(9.939) \\
\end{array}$ & $\begin{array}{c}-2.276 \\
(-8.220) \\
\end{array}$ & $\begin{array}{c}1.424 \\
(1.815) \\
\end{array}$ \\
\hline Thailand & $\begin{array}{c}-6.569 \\
(-6.863) \\
\end{array}$ & $\begin{array}{c}-32.291 \\
(-13.339) \\
\end{array}$ & $\begin{array}{c}1.694 \\
(2.828) \\
\end{array}$ & $\begin{array}{c}3.104 \\
(9.822) \\
\end{array}$ & $\begin{array}{c}0.527 \\
(0.696) \\
\end{array}$ & $\begin{array}{c}-9.158 \\
(-14.187) \\
\end{array}$ \\
\hline Czech Rep. & $\begin{array}{c}2.488 \\
(9.895) \\
\end{array}$ & $\begin{array}{l}-115.443 \\
(-13.918)\end{array}$ & $\begin{array}{c}8.367 \\
(8.114)\end{array}$ & $\begin{array}{c}7.528 \\
(7.031)\end{array}$ & $\begin{array}{c}-8.175 \\
(-3.243)\end{array}$ & $\begin{array}{l}14.635 \\
(2.039)\end{array}$ \\
\hline Hungary & $\begin{array}{c}0.622 \\
(3.073)\end{array}$ & $\begin{array}{c}-33.580 \\
(-10.585)\end{array}$ & $\begin{array}{c}2.458 \\
(5.972)\end{array}$ & $\begin{array}{c}2.724 \\
(5.065)\end{array}$ & $\begin{array}{c}-3.249 \\
(-13.515)\end{array}$ & $\begin{array}{c}11.904 \\
(21.556)\end{array}$ \\
\hline Poland & $\begin{array}{c}0.640 \\
(2.143)\end{array}$ & $\begin{array}{l}-112.201 \\
(-21.644)\end{array}$ & $\begin{array}{c}8.582 \\
(12.886)\end{array}$ & $\begin{array}{c}3.535 \\
(3.963) \\
\end{array}$ & $\begin{array}{c}-1.287 \\
(-0.698) \\
\end{array}$ & $\begin{array}{c}0.841 \\
(0.091)\end{array}$ \\
\hline Romania & $\begin{array}{c}-0.623 \\
(-5.427)\end{array}$ & $\begin{array}{c}-6.345 \\
(-5.073)\end{array}$ & $\begin{array}{c}1.849 \\
(7.840) \\
\end{array}$ & $\begin{array}{c}2.589 \\
(8.329)\end{array}$ & $\begin{array}{c}-1.236 \\
(-4.398)\end{array}$ & $\begin{array}{c}6.830 \\
(6.423) \\
\end{array}$ \\
\hline Russia & $\begin{array}{c}0.229 \\
(2.109) \\
\end{array}$ & $\begin{array}{c}-12.941 \\
(-14.786) \\
\end{array}$ & $\begin{array}{c}5.705 \\
(13.448) \\
\end{array}$ & $\begin{array}{c}0.302 \\
(1.059) \\
\end{array}$ & $\begin{array}{c}-1.044 \\
(-5.818) \\
\end{array}$ & $\begin{array}{r}12.132 \\
(4.944) \\
\end{array}$ \\
\hline Israel & $\begin{array}{c}2.858 \\
(9.520) \\
\end{array}$ & $\begin{array}{c}-57.841 \\
(-22.545) \\
\end{array}$ & $\begin{array}{c}8.015 \\
(5.619) \\
\end{array}$ & $\begin{array}{c}-0.389 \\
(-0.271) \\
\end{array}$ & $\begin{array}{c}6.159 \\
(9.374) \\
\end{array}$ & $\begin{array}{c}-7.974 \\
(-11.117) \\
\end{array}$ \\
\hline South Africa & $\begin{array}{c}0.666 \\
(3.139)\end{array}$ & $\begin{array}{c}6.954 \\
(4.147)\end{array}$ & $\begin{array}{c}-0.901 \\
(-5.047)\end{array}$ & $\begin{array}{c}10.242 \\
(14.262)\end{array}$ & $\begin{array}{c}-4.469 \\
(-8.509)\end{array}$ & $\begin{array}{l}17.408 \\
(3.247)\end{array}$ \\
\hline
\end{tabular}

Note: This table reports the results from the estimation of Equation (16), $s_{i t+1}-s_{i t}=\beta_{i}^{\prime}\left(i_{i t}-i_{t}^{U S}\right)+\alpha_{i}^{\prime}+\lambda_{i} d_{i t}+\varepsilon_{i t+1}$, where $s_{i t+1}-s_{i t}$ is the one-year change in exchange rate versus dollar, $\left(i_{i t}-i_{t}^{U S}\right)$ the one-year interest-rate with the US, $d_{i t}$ is the sovereign CDS premium proxing the default risk. $t$ statistics are given in parentheses. 


\section{LIST OF WORKING PAPERS RELEASED BY CEPII}

An Exhaustive list is available on the website: Ilwww.cepii.fr.

\section{NO}

Title

Authors

\section{1}

2011-16 Occupation-Eduction Mismatch of Immigrant Workers in Europe: Context and Policies

2011-15 Does Importing more Inputs Raise Exports? Firm Level Evidence from France

2011-14 Joint Estimates of Automatic and Discretionary Fiscal Policy: the OECD 1981-2003

2011-13 Immigration, vieillissement démographique et financement de la protection sociale : une évaluation par l'équilibre général calculable appliqué à la France

2011-12 The Performance of Socially responsible funds: does the screening process matter?

2011-11 Market Size, Competition, and the Product Mix of Exporters

2011-10 The Trade Unit Values Database

2011-09 Carbon Price Drivers: Phase I versus Phase II Equilibrium?

2011-08 Rebalancing Growth in China:

An International Perspective

2011-07 Economic Integration in the EuroMed: Current Status and Review of Studies

2011-06 The Decision to Import Capital Goods in India: Firms' Financial Factors Matter

2011-05 FDI from the South: the role of institutional distance and natural resources
M. Aleksynska \& A. Tritah

M. Bas \& V. Strauss-Kahn

J. Darby \& J. Mélitz

X. Chojnicki \& L. Ragot

G. Capelle-Blancard \&

S. Monjon

T. Mayer, M. Melitz \&

G. Ottaviano

A. Berthou \& C. Emlinger

A.Creti, P-A. Jouvet, \&

V Mignon

A. Bénassy-Quéré, B.

Carton \& L. Gauvin

J. Jarreau

A. Berthou \& M. Bas

M. Aleksynska

O. Havrylchyk 
2011-04b What International Monetary System for a fastchanging World Economy?

2011-04a Quel système monétaire international pour une économie mondiale en mutation rapide ?

2011-03 China's Foreign Trade in the Perspective of a more Balanced Economic Growth

2011-02 The Interactions between the Credit Default Swap and the Bond Markets in Financial Turmoil

2011-01 Comparative Advantage and Within-Industry Firms Performance

\section{0}

2010-33 Export Performance and Credit Constraints in China

2010-32 Export Performance of China's Domestic Firms: the Role of Foreign Export Spillovers

2010-31 Wholesalers in International Trade

2010-30 TVA et taux de marge : une analyse empirique sur données d'entreprises

2010-29 Economic and cultural assimilation and integration of immigrants in europe

2010-28 Les firmes françaises dans le commerce de service

2010-27 The World Economy in 2050: a Tentative Picture

2010-26 Determinants and Pervasiveness of the Evasion of Customs Duties

2010-25

On the Link between Credit Procyclicality and Bank Competition

2010-24

Are Derivatives Dangerous? A Literature Survey

2010-23 BACI: International Trade Database at the Product-level The 1994-2007 Version
A. Bénassy-Quéré \& J. Pisani-Ferry

A. Bénassy-Quéré \& J. Pisani-Ferry

G. Gaulier, F. Lemoine \& D. Ünal

V. Coudert \& M. Gex

M. Crozet \& F. Trionfetti

J. Jarreau \& S. Poncet

F. Mayneris \& S. Poncet

M. Crozet, G. Lalanne \& S. Poncet

P. Andra, M. Carré \& A. Bénassy-Quéré

M. Aleksynska \& Y. Algan

G. Gaulier, E. Milet \& D. Mirza

J. Fouré,

A. Bénassy-Quéré \& L. Fontagné

S. Jean \& C. Mitaritonna

V. Bouvatier, A. Lopez-Villavicencio \& V. Mignon

G. Capelle-Blancard

G. Gaulier S. Zignago 
2010-22 Indirect Exporters

F. McCann

2010-21 Réforme des retraites en France : évaluation de la mise en

X. Chojnicki place d'un système par comptes notionnels

R. Magnani

2010-20 The Art of Exceptions:

Sensitive Products in the Doha Negotiations

C. Gouel

C. Mitaritonna

M.P Ramos

2010-19 Measuring Intangible Capital Investment: an Application to

V. Delbecque the "French data"

L. Nayman

2010-18 Clustering the Winners: The French Policy of Competitiveness Clusters

L. Fontagné, P. Koenig, F.

Mayneris \& S. Poncet

2010-17 The Credit Default Swap Market and the Settlement of Large Defauts

V. Coudert \& M. Gex

2010-16 The Impact of the 2007-10 Crisis on the Geography of Finance

G. Capelle-Blancard $\&$ Y. Tadjeddine

2010-15 Socially Responsible Investing: it takes more than Words

G. Capelle-Blancard \& S. Monjon

V. Salins

2010-14 A Case for Intermediate Exchange-Rate Regimes

2010-13 Gold and Financial Assets: Are There Any Safe Havens in Bear Markets?

\& A. Bénassy-Quéré

V. Coudert \& H. Raymond

2010-12 European Export Performance

A. Cheptea, L. Fontagné \& S. Zignago 
Organisme public d'étude et de recherche en économie internationale, le CEPII est placé auprès du Centre d'Analyse Stratégique. Son programme de travail est fixé par un conseil composé de responsables de l'administration et de personnalités issues des entreprises, des organisations syndicales et de l’Université.

Les documents de travail du CEPII mettent à disposition du public professionnel des travaux effectués au CEPII, dans leur phase d'élaboration et de discussion avant publication définitive. Les documents de travail sont publiés sous la responsabilité de la direction du CEPII et n'engagent ni le conseil du Centre, ni le Centre d'Analyse Stratégique. Les opinions qui y sont exprimées sont celles des auteurs.

Les documents de travail du CEPII sont disponibles sur le site : http//www.cepii.fr 